\title{
Conservation characteristics of wilted perennial ryegrass silage made using biological or chemical additives
}

\author{
P. Conaghan, ${ }^{*} \dagger^{1}$ P. O’Kiely, ${ }^{*}$ and F. P. O'Mara† \\ ${ }^{*}$ Teagasc, Grange Beef Research Centre, Dunsany, Co. Meath, Ireland \\ †UCD School of Agriculture, Food Science and Veterinary Medicine, University College Dublin, Belfield, Dublin 4, Ireland
}

\begin{abstract}
The effects of 7 additive treatments on the fermentation and aerobic stability characteristics of wilted grass silage were studied under laboratory conditions. Treatments included no additive applied (untreated control), ammonium tetraformate at 3 and $6 \mathrm{~L} / \mathrm{t}$, homofermentative lactic acid bacteria alone ( $\left.{ }^{\text {ho }} \mathrm{LAB}\right)$, a mixture of Lactobacillus buchneri plus homofermentative lactic acid bacteria ( ${ }^{\text {he }}$ ho $\mathrm{LAB}$ ), and an antimicrobial mixture of sodium benzoate, sodium propionate, sodium nitrite, and hexamethylenetetramine at 2.5 and $5 \mathrm{~L} / \mathrm{t}$. Additives were compared across 3 consecutive harvests of 2 perennial ryegrass cultivars (AberDart and Fennema) following a 24-h wilt. Silos were opened after at least $100 \mathrm{~d}$ of ensilage and aerobic stability was assessed. Season of harvest had a large effect on grass composition at ensiling, producing herbages of relatively low (approximately $145 \mathrm{~g} / \mathrm{kg}$ ), medium (approximately 250 $\mathrm{g} / \mathrm{kg}$ ), and high (approximately $365 \mathrm{~g} / \mathrm{kg}$ ) dry matter (DM) concentrations. Within harvests there were lesser differences between cultivars. The untreated control and ${ }^{\text {ho }} \mathrm{LAB}$ additive produced badly fermented silage from the low-DM herbages and well-fermented silage from the medium- and high-DM herbages. The ammonium tetraformate treatments produced both well-fermented and badly fermented silage from the low-DM herbages depending on cultivar, and consistently well-fermented silage from the medium- and high-DM herbages. The ${ }^{\text {he }+ \text { ho }}$ LAB silages had similar or slightly lower standard of fermentation than the untreated and ${ }^{\text {ho }} \mathrm{LAB}$ silages. The antimicrobial mixture produced more silages of lower standard of fermentation than the untreated control and ammonium tetraformate and ${ }^{\text {ho }} \mathrm{LAB}$ additives. All additive treatments, including the untreated control, failed to consistently increase residual water-soluble carbohydrate concentrations at silo opening. Ammonium tetraformate at $6 \mathrm{~L} / \mathrm{t}$ was the most successful and ${ }^{\text {he+ho }} \mathrm{LAB}$ the least successful additive at increasing
\end{abstract}

Received October 20, 2008.

Accepted September 9, 2009.

${ }^{1}$ Corresponding author: patrick.conaghan@teagasc.ie residual WSC concentrations. The ${ }^{\text {ho }} \mathrm{LAB}$ silages were generally the least aerobically stable. Silages treated with ammonium tetraformate at $6 \mathrm{~L} / \mathrm{t}$ were relatively stable under aerobic conditions. The ${ }^{\text {he+ho }} \mathrm{LAB}$ additive and antimicrobial mixture had an inconsistent effect on aerobic stability. Overall, ammonium tetraformate at $6 \mathrm{~L} / \mathrm{t}$ was the most effective additive evaluated in this study, producing generally well-fermented silage with the highest concentrations of residual WSC and an intermediate to long duration of aerobic stability.

Key words: perennial ryegrass silage, water-soluble carbohydrate, Lactobacillus buchneri, antimicrobial mixture

\section{INTRODUCTION}

Intensive dairy farming systems based on grazed grass plus grass silage are dependent on the use of high inputs of $\mathrm{N}$ fertilizer to provide sufficient yields of herbage DM in order to sustain milk production at economically attractive levels (Jarvis et al., 1996). Ensiling such heavily fertilized swards typically results in silages with high levels of rumen-degradable $\mathrm{N}$ and low levels of readily fermentable energy, leading to a low efficiency of utilization of silage $\mathrm{N}$ for milk production (Shingfield et al., 2001). The inefficient capture of dietary $\mathrm{N}$ from grass silage is a key factor in relation to the substantial excretion of $\mathrm{N}$ by ruminants (Givens and Rulquin, 2004).

The concern about excessive $\mathrm{N}$ loss to the environment from agricultural processes has stimulated the investigation of various mitigation strategies. One means of improving the efficiency of $\mathrm{N}$ utilization in diets based on grass silage is to increase the residual water-soluble carbohydrate (WSC) concentration in silage (Merry et al., 2006). The WSC offer a valuable source of readily fermentable energy for microbial $\mathrm{N}$ synthesis. The low utilization of $\mathrm{N}$ from grass silage has been attributed primarily to the low efficiency of capture of rumendegradable $\mathrm{N}$ caused by a limited supply of fermentable energy for rumen microbes (Givens and Rulquin, 2004). However, increasing the residual WSC in silage may adversely affect its aerobic stability at feed-out owing to more rapid fungal growth on WSC than on 
fermentation products (Muck and Bolsen, 1991). The aerobic deterioration of silage is undesirable because it reduces the nutritional value and, in particular, the concentration of residual WSC and increases the risk of proliferation of potentially pathogenic or otherwise undesirable microorganisms (McDonald et al., 1991).

Rapid wilting of herbage preensiling under suitable drying conditions has been widely adopted and encouraged as a means of aiding silage fermentation and management, and typically results in silage with greater residual WSC concentration (McDonald et al., 1991). The availability of grass cultivars bred for higher concentrations of herbage WSC (Conaghan et al., 2008) offers the potential of further increasing the residual WSC concentration in silage. However, wilted silages are particularly susceptible to aerobic deterioration (McDonald et al., 1991) and ensiling high-WSC cultivars may further increase the susceptibility to aerobic deterioration.

Additives have been developed to help improve the aerobic stability of silages. Inoculation with a mixture containing the heterofermentative strain of lactic acid bacteria (LAB) Lactobacillus buchneri and homofermentative LAB has been successful at improving the aerobic stability and standard of fermentation of wilted grass silage (Driehuis et al., 2001). Generally, inoculation with $L$. buchneri alone or in combination with homofermentative $\mathrm{LAB}$ has resulted in lower concentrations of residual WSC in silages (Driehuis et al., 2001; Kleinschmit and Kung, 2006). However, if aerobic stability is improved, the loss of WSC incurred by the addition of L. buchneri may be moderate in comparison with what might have been lost at feed-out through aerobic deterioration. In lieu of biological additives, a mixture of sodium benzoate $(\mathrm{NaB})$, sodium propionate $(\mathrm{NaP})$, sodium nitrite $(\mathrm{NaN})$, and hexamethylenetetramine (hexamine) offers a chemical alternative. A chemical additive may be more robust than a biological additive whose effectiveness is subject to available substrate, sufficient moisture for growth, and the competiveness of the indigenous epiphytic microbial population (Kung et al., 2003). The application of an antimicrobial mixture of $\mathrm{NaB}, \mathrm{NaP}, \mathrm{NaN}$, and hexamine resulted in improved aerobic stability and fermentation in wilted grass silages in several studies (Lingvall and Lättemäe, 1999; Knický and Lingvall, 2004; McEniry et al., 2007). These studies also found that the antimicrobial mixture often increased residual WSC concentration in silages at silo opening.

Because crop composition at harvest, and management and environmental conditions during harvest and storage, have such a major effect on the ensiling process, the relative efficacy of a range of additives can be measured accurately only within the same comparative experiment. To the authors' knowledge, inoculation with a mixture of $L$. buchneri plus homofermentative $\mathrm{LAB}$ and the application of an antimicrobial mixture of $\mathrm{NaB}, \mathrm{NaP}, \mathrm{NaN}$, and hexamine have not previously been directly compared as additives for wilted grass silage in a comparative experiment.

The objective of this study was to quantify the effects of (1) inoculation with a mixture of $L$. buchneri plus homofermentative LAB and (2) 2 different application rates of an antimicrobial mixture of $\mathrm{NaB}, \mathrm{NaP}, \mathrm{NaN}$, and hexamine on the conservation characteristics of wilted grass silage made from perennial ryegrass (Lolium perenne L.) cultivars bred for normal or higher concentrations of herbage WSC. To benchmark the effects of these additives on wilted grass silage, herbage was also ensiled without additive application (untreated) and with frequently used additives. The frequently used additives evaluated were ammonium tetraformate at an application rate of 3 and $6 \mathrm{~L} / \mathrm{t}$ and an inoculant consisting solely of homofermentative LAB. All treatments were evaluated and compared over 3 consecutive harvests so as to provide a broader view of the extent and consistency of additive effects on silage characteristics. The optimum additive treatment should be effective in (1) securing a medium or preferably higher standard of fermentation, (2) enhancing residual WSC, and (3) protecting aerobic stability.

\section{MATERIALS AND METHODS}

\section{Treatments}

The effects of 7 additive treatments (Table 1 ) on the silage characteristics of 2 perennial ryegrass cultivars (AberDart and Fennema) were determined at 3 harvests using laboratory silos. Treatments included no additive applied (untreated control); ammonium tetraformate at $3 \mathrm{~L} / \mathrm{t}$ (AT-lo); ammonium tetraformate at $6 \mathrm{~L} / \mathrm{t}$ (AT-hi); homofermentative LAB alone $\left({ }^{\text {ho }} \mathbf{L A B}\right)$; L. buchneri plus homofermentative LAB $\left({ }^{\text {he }+ \text { ho }} \mathbf{L A B}\right)$; a mixture of $\mathrm{NaB}, \mathrm{NaP}, \mathrm{NaN}$, and hexamine at 2.5 L/t (AM-lo); and a mixture of NaB, NaP, NaN, and hexamine at $5 \mathrm{~L} / \mathrm{t}$ (AM-hi). Cultivar AberDart was bred for high concentrations of herbage WSC (Moorby, 2001). Cultivar Fennema was not bred for WSC concentration and may be considered to represent perennial ryegrass cultivars with normal concentrations of WSC. Both AberDart and Fennema are diploid with similar heading dates (AberDart = May 27; Fennema = May 28). The experiment was conducted at the Teagasc Grange Beef Research Centre (Dunsany, Ireland; $53^{\circ} 30^{\prime} \mathrm{N}, 6^{\circ} 40^{\prime} \mathrm{W}$ and $83 \mathrm{~m}$ above sea level). 


\section{Silage Preparation}

Cultivars were sown as pure swards in adjacent 0.1-ha plots in mid September and harvested on 3 successive occasions during the following year: May 22 (harvest 1), July 3 (harvest 2), and August 28 (harvest 3). A compound fertilizer $(240 \mathrm{~g}$ of $\mathrm{N}, 25 \mathrm{~g}$ of $\mathrm{P}$, and $100 \mathrm{~g}$ of $\mathrm{K} / \mathrm{kg}$ ) was applied, supplying $113 \mathrm{~kg}$ of $\mathrm{N}, 12 \mathrm{~kg}$ of $\mathrm{P}$, and $47 \mathrm{~kg}$ of K/ha in late March; $94 \mathrm{~kg}$ of N, $10 \mathrm{~kg}$ of $\mathrm{P}$, and $39 \mathrm{~kg}$ of $\mathrm{K} /$ ha immediately after harvest 1 ; and $75 \mathrm{~kg}$ of $\mathrm{N}, 8 \mathrm{~kg}$ of $\mathrm{P}$, and $31 \mathrm{~kg}$ of $\mathrm{K} /$ ha immediately after harvest 2. At each harvest, plots were cut, tedded, rowed, and harvested using standard field equipment: mower-conditioner (JF CMT 245, Sønderborg, Denmark) set at 5-cm cutting height, rotary tedder (Krone KS 380-420/12 Vario, Spelle, Germany), and precisionchop harvester (Pöttinger Mex VI, Grieskirchen, Austria) with a $19-\mathrm{mm}$ theoretical cutting length. Crops were ensiled after a 24 -h wilt.

Before ensiling, the harvested herbage was thoroughly mixed and sampled $(\mathrm{n}=6)$ for chemical analysis. Subsamples of AberDart and Fennema (each $6 \mathrm{~kg}$ of fresh herbage) were allocated at random to 1 of the 7 additive treatments, with 3 replicates per additive-cultivar combination. Herbage and additive were manually mixed. Five kilograms of herbage from each 6-kg quantity was then ensiled in laboratory pipe silos (height $=0.75 \mathrm{~m}$; i.d. $=0.15 \mathrm{~m})$ as described by O'Kiely and Wilson (1991). This gave an approximate herbage density at ensiling of $500 \mathrm{~kg} / \mathrm{m}^{3}$. Aseptic techniques were used to prevent cross-contamination between treatments. Silos were stored indoors at $15^{\circ} \mathrm{C}$ until opening after 113 , 107 , and $100 \mathrm{~d}$ of ensilage for harvests 1,2 , and 3 , respectively.

\section{Silage Measurements}

On opening each silo, the silage was weighed and sampled for chemical analysis. Silage DM recovery was calculated as silage DM recovered from a silo expressed as a proportion of the herbage DM ensiled. Aerobic stability and deterioration were assessed on 2 replicates of each additive-cultivar combination as follows. Samples of $4 \mathrm{~kg}$ each were incubated at 20 to $23^{\circ} \mathrm{C}$ in a polythene-lined polystyrene (2.5-cm thick) box (59 $\times 39 \times 22 \mathrm{~cm})$ with a polystyrene lid loosely fitted. Samples from harvests 1, 2, and 3 were stored under these conditions for 15, 10, and $8 \mathrm{~d}$, respectively. Silage temperatures were monitored daily. Containers of water stored near the silage acted as reference temperatures to which all silage temperatures were compared. Aerobic stability was defined as the number of days silage was exposed to air before a $2^{\circ} \mathrm{C}$ increase in temperature above the reference temperature. Aerobic deterioration 
was defined as the sum of the daily temperature increases $\left({ }^{\circ} \mathrm{C}\right)$ above the reference temperature in the first $5 \mathrm{~d}$ of aerobiosis.

\section{Chemical Analysis}

Fresh herbage and silage samples were stored at $-18^{\circ} \mathrm{C}$ before analysis. Frozen samples were subsequently thawed and chopped through a mincer (Müller food processor, type MTK 204 special, Saarbrücken, Germany). Subsamples of preensiled herbage were then (1) dried in a forced-air circulation oven at $98^{\circ} \mathrm{C}$ for $16 \mathrm{~h}$ to estimate DM concentration and (2) dried in a forced air-circulation oven at $40^{\circ} \mathrm{C}$ for $48 \mathrm{~h}$, milled with a Retsch impeller-type cutting mill (Retsch $\mathrm{GmbH}$ and Co. K.G., Haan, Germany) to a 1-mm particle size, and analyzed for buffering capacity, ash, in vitro DM digestibility, WSC, NDF, ADF, and CP. Following thawing and chopping, subsamples of silage were (1) dried in a forced-air circulation oven at $85^{\circ} \mathrm{C}$ for 16 $\mathrm{h}$ and corrected for loss of volatile components during drying according to Porter and Murray (2001) to estimate DM concentration; (2) dried in a forced-air circulation oven at $40^{\circ} \mathrm{C}$ for $48 \mathrm{~h}$, milled as described above, and analyzed for CP; and (3) manually compressed and the expressed aqueous extract analyzed for $\mathrm{pH}$, WSC, ammonia-N, lactic acid, volatile fatty acids (acetic, propionic, and butyric acids), and ethanol.

Buffering capacity was measured by the method of Playne and McDonald (1966). Ash was estimated following complete combustion in a muffle furnace at $550^{\circ} \mathrm{C}$ for $5 \mathrm{~h}$. In vitro DM digestibility was determined by the method of Tilley and Terry (1963) with the modification that the final residue was isolated by filtration rather than by centrifugation. Herbage WSC was estimated using near-infrared spectroscopy (NIR Systems, Perstorp Analytical, Berkshire, UK) as described by Lister and Dhanoa (1998). Silage WSC was determined using the colorimetric method of Wilson (1978). Neutral detergent fiber and ADF were analyzed according to Van Soest (1967). Crude protein was measured using an N analyzer (Leco FP-428, Leco Instruments Inc., St. Joseph, MI) according to the methods of AOAC (990-03; AOAC, 1990). The $\mathrm{pH}$ was determined using a $\mathrm{pH}$ electrode. Ammonia-N was estimated colorimetrically by a modification of the phenol-hypochlorite technique (O'Keeffe and Sherrington, 1983). Ammonia$\mathrm{N}$ concentrations for treatments containing ammonium tetraformate, NaN, or hexamine were corrected for the maximum potential contribution of additive-derived ammonia-N. If ammonia- $\mathrm{N}$ expressed as a proportion of total $\mathrm{N}$ is used as an indicator of proteolytic activity (McDonald et al., 1991), the uncorrected values may overstate the extent of proteolysis. Uncorrected ammonia- $\mathrm{N}$ concentrations were measured. Lactic acid was measured using the Boeringer Mannheim method (catalog no. 139084) on a Ciba-Corning Diagnostics 550 Express Clinical Chemistry Analyzer (Oberlin, OH). Volatile fatty acids and ethanol were determined using gas liquid chromatography (Ranfft, 1973).

Fermentation products were calculated as the sum of lactic acid, volatile fatty acids, and ethanol, expressed on a DM basis. Lactic acid concentration was expressed as a percentage of the fermentation products $(\mathbf{L A}: \mathbf{F P})$. The standard of fermentation of silages was classified on a 1 to 5 scale, where $1=$ very bad, $2=$ bad, $3=$ medium, $4=$ good, and $5=$ excellent. Silages with $\leq 50 \% \mathrm{LA}: \mathrm{FP}$ and $\geq 25 \mathrm{~g} / \mathrm{kg}$ of DM of butyric acid were classified as very bad, $\leq 50 \% \mathrm{LA}: \mathrm{FP}$ and $<25 \mathrm{~g} / \mathrm{kg}$ of DM of butyric acid as bad, 50 to $60 \%$ LA:FP as medium, 61 to $70 \%$ LA:FP as good, and $>70 \%$ LA:FP as excellent standard of fermentation.

\section{Statistical Analysis}

Mean chemical composition of fresh herbage from AberDart and Fennema and harvests 1, 2, and 3 at ensiling were compared by $t$-test (PROC TTEST, SAS Institute Inc., Cary, NC). Silage data were analyzed separately for each harvest by ANOVA (PROC GLM, SAS Institute Inc.) according to the completely randomized design model

$$
Y_{i j}=\mu+C_{i}+A_{j}+C A_{i j}+\varepsilon_{i j},
$$

where $Y_{i j}$ is the observation made on the $i$ th cultivar treated with the $j$ th additive, $\mu$ is the overall mean, $C_{i}$ is the effect of cultivar $(i=2), A_{j}$ is the effect of additive $(j=7)$, and $\varepsilon_{i j}$ is the residual error. All factors were considered fixed. Differences among means were tested using Fisher's (protected) least-significant difference. The aerobic stability and deterioration values from harvests 2 and 3 were not analyzed by ANOVA because several treatments failed to exhibit measureable changes in temperature during the period of assessment. Treatment means for aerobic stability and deterioration from harvests 2 and 3 were compared by $t$-test (PROC TTEST, SAS Institute Inc.). Significance was declared at $P<0.05$.

\section{RESULTS}

\section{Herbage Composition at Ensiling}

Harvests 1, 2, and 3 had relatively high, low, and intermediate concentrations of both DM and WSC, respectively (Table 2). The mean DM concentration of harvests 1,2 , and 3 was 366,146 , and $250 \mathrm{~g} / \mathrm{kg}$, respec- 
Table 2. Chemical composition (mean $\pm \mathrm{SD}$ of 6 samples) of the perennial ryegrass cultivars, ${ }^{1}$ AberDart and Fennema, at ensiling of each harvest $^{2}$

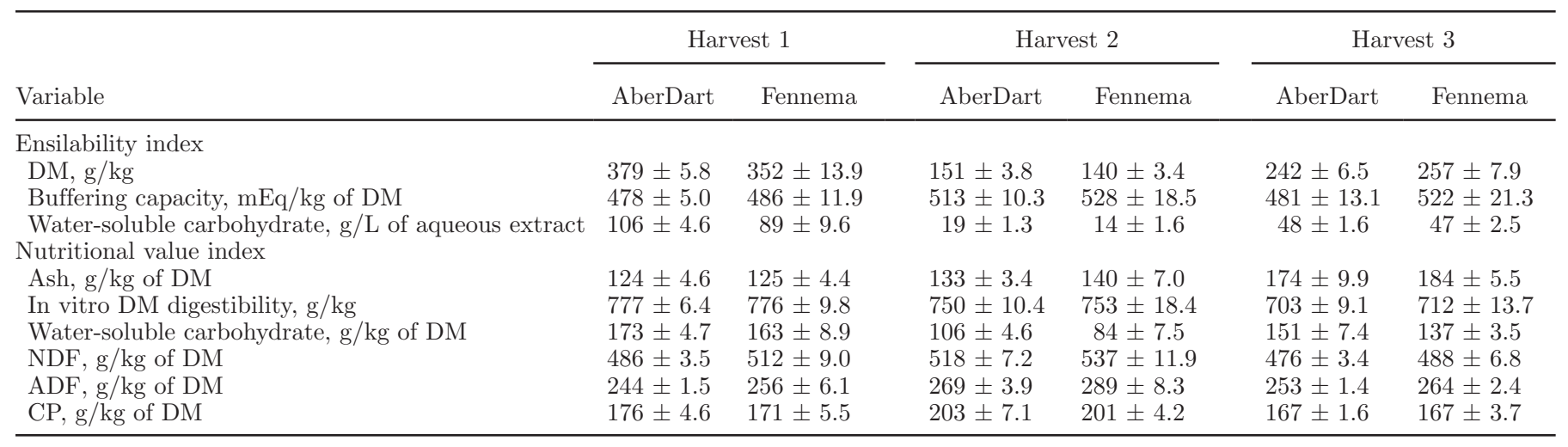

${ }^{1}$ AberDart $=$ perennial ryegrass cultivar selected for high concentrations of herbage water-soluble carbohydrate; Fennema $=$ control.

${ }^{2}$ Harvest $1=$ primary growth; harvest $2=$ first regrowth; harvest $3=$ second regrowth.

tively. Corresponding concentrations of WSC expressed on a DM basis were 168,95 , and $144 \mathrm{~g} / \mathrm{kg}$ of $\mathrm{DM}$ and in the aqueous extract were 98,17 , and $48 \mathrm{~g} / \mathrm{L}$. All herbages had relatively high buffering capacity $(>475 \mathrm{mEq} /$ $\mathrm{kg}$ of DM) and DM digestibility (>700 g/ $\mathrm{kg}$ ) values.

Compared with Fennema, AberDart had higher $(P$ $<0.05$ or less) concentrations of WSC expressed on a DM basis at all harvests and higher $(P<0.05$ or less $)$ concentrations of WSC expressed in the aqueous extract at 2 out of 3 harvests. The WSC advantage of AberDart over Fennema ranged from 10 to $26 \mathrm{~g} / \mathrm{kg}$ of DM or 5 to $17 \mathrm{~g} / \mathrm{L}$, depending on the harvest. AberDart had higher $(P<0.01)$ buffering capacity than Fennema at harvest 3 , but otherwise there were no differences between cultivars in buffering capacity. Cultivars differed $(P<0.05$ or less) in DM concentration at all harvests, with the difference ranging from 11 to $27 \mathrm{~g} / \mathrm{kg}$. AberDart had lower $(P<0.05$ or less $)$ DM concentrations than Fennema at 2 harvests. Differences between AberDart and Fennema in DM digestibility were nonsignificant at all harvests with the difference ranging from 1 to $8 \mathrm{~g} / \mathrm{kg}$.

\section{Silage}

Table 3 presents the standard of fermentation classification, chemical composition, silage DM recovery, aerobic stability, and aerobic deterioration of each additive-cultivar-harvest combination. The main effects of additive and cultivar were frequently found significant for most variables. However, the effects of additive and cultivar were often not independent of each other, as indicated by the significant additive $\times$ cultivar interactions. Interactions were caused by changes in the magnitude and ranking of additive means across cultivars. If the interaction was significant, the main effects of additive and cultivar were disregarded and not described in the results. Only the most pertinent comparisons among additive treatments are described in this paper. Each additive treatment is not compared against every other additive treatment, considering that 21 different comparisons are possible within each harvest. However, the means, error terms, and level of significance for each additive-cultivar combination are presented in Table 3 , allowing the reader to make any or all comparisons of interest. An overview of the effects of additive and cultivar across all harvests is summarized in Table 4 for ease of interpretation and comparison.

Untreated. The untreated (no additive applied) control produced silages classed as excellent $(\mathrm{n}=4)$, bad $(n=1)$, or very bad $(n=1)$ standard of fermentation depending on cultivar-harvest combination. From AberDart and Fennema at harvests 1 and 3, the untreated silages underwent a lactic acid-dominant fermentation and produced silage of excellent standard of fermentation with a high percentage of LA:FP $(\geq 74 \%)$, relatively low $\mathrm{pH}(\leq 4.5)$, and low concentrations of ammonia-N (corrected; $<93 \mathrm{~g} / \mathrm{kg}$ of $\mathrm{N}$ ), butyric acid $(\leq 2 \mathrm{~g} / \mathrm{kg}$ of $\mathrm{DM})$, and ethanol $(\leq 16 \mathrm{~g} / \mathrm{kg}$ of DM). In contrast, AberDart and Fennema from harvest 2 produced badly and very badly fermented untreated silages, respectively. Both herbages underwent an acetic acid-dominant fermentation, producing silages with a low percentage of LA:FP (8\%), high $\mathrm{pH}(\geq 5.4)$, high concentrations of ammonia- $\mathrm{N}$ (corrected; $\geq 238 \mathrm{~g} / \mathrm{kg}$ of $\mathrm{N})$ and butyric acid ( $\geq 16 \mathrm{~g} / \mathrm{kg}$ of $\mathrm{DM})$, and low to high concentrations of ethanol $(2-24 \mathrm{~g} / \mathrm{kg}$ of DM). The very badly fermented silage had 2.3 and 2.4 times higher ammonia- $\mathrm{N}$ (corrected) and butyric acid concentrations than the badly fermented silage, respectively. Silages from harvest 1 contained between 11 and $27 \mathrm{~g} / \mathrm{kg}$ of DM of residual WSC. Silages from harvests 2 and 3 contained only trace quantities of residual WSC $(\leq 2 \mathrm{~g} /$ 
Table 3. Cultivar ${ }^{1}$ and additive ${ }^{2}$ effects on the conservation characteristics of perennial ryegrass silages as removed from the silos

\begin{tabular}{|c|c|c|c|c|c|c|c|c|c|c|c|c|c|c|c|c|c|c|}
\hline \multirow[b]{2}{*}{ Variable $^{3}$} & \multicolumn{2}{|c|}{ None } & \multicolumn{2}{|c|}{ AT-lo } & \multicolumn{2}{|c|}{ AT-hi } & \multicolumn{2}{|c|}{${ }^{\text {ho }} \mathrm{LAB}$} & \multicolumn{2}{|c|}{${ }^{\text {he }+ \text { ho }} \mathrm{LAB}$} & \multicolumn{2}{|c|}{ AM-lo } & \multicolumn{2}{|c|}{ AM-hi } & \multirow[b]{2}{*}{$\mathrm{SEM}^{4}$} & \multicolumn{3}{|c|}{$P$-value ${ }^{5}$} \\
\hline & Aber & Fenn & Aber & Fenn & Aber & Fenn & Aber & Fenn & Aber & Fenn & Aber & Fenn & Aber & Fenn & & $\mathrm{C}$ & A & $\mathrm{C} \times \mathrm{A}$ \\
\hline \multicolumn{19}{|l|}{ Harvest 1} \\
\hline Standard of fermentation & 5.0 & 5.0 & 5.0 & 5.0 & 5.0 & 5.0 & 5.0 & 5.0 & 4.0 & 3.7 & 5.0 & 5.0 & 5.0 & 5.0 & 0.18 & & $* * *$ & \\
\hline $\mathrm{DM}, \mathrm{g} / \mathrm{kg}$ & 374 & 334 & 375 & 339 & 375 & 332 & 379 & 328 & 372 & 331 & 376 & 333 & 381 & 334 & 4.9 & $* * *$ & & \\
\hline $\mathrm{pH}$ & 4.5 & 4.3 & 4.5 & 4.3 & 4.5 & 4.4 & 4.0 & 4.1 & 4.3 & 4.3 & 4.4 & 4.4 & 4.5 & 4.5 & 0.03 & $*$ & $* * *$ & $* * *$ \\
\hline $\mathrm{NH}_{3}-\mathrm{N}$ uncorrected, $\mathrm{g} / \mathrm{kg}$ of $\mathrm{N}$ & 65 & 72 & 68 & 81 & 71 & 87 & 41 & 48 & 61 & 67 & 71 & 75 & 74 & 78 & 3.0 & $* * *$ & $* * *$ & \\
\hline $\mathrm{NH}_{3}-\mathrm{N}$ corrected, $\mathrm{g} / \mathrm{kg}$ of $\mathrm{N}$ & 65 & 72 & 53 & 63 & 39 & 51 & 41 & 48 & 61 & 67 & 58 & 60 & 49 & 48 & 3.1 & $* * *$ & $* * *$ & \\
\hline $\mathrm{CP}, \mathrm{g} / \mathrm{kg}$ of $\mathrm{DM}$ & 173 & 172 & 173 & 170 & 175 & 173 & 176 & 176 & 177 & 181 & 171 & 170 & 173 & 170 & 1.6 & & $* * *$ & \\
\hline WSC, $\mathrm{g} / \mathrm{kg}$ of DM & 27 & 11 & 42 & 27 & 59 & 41 & 30 & 13 & 6 & 6 & 31 & 19 & 40 & 33 & 1.8 & $* * *$ & $* * *$ & $* * *$ \\
\hline Lactic acid, $\mathrm{g} / \mathrm{kg}$ of DM & 73 & 87 & 63 & 79 & 44 & 58 & 95 & 104 & 79 & 89 & 78 & 83 & 72 & 70 & 3.1 & $* * *$ & $* * *$ & \\
\hline Acetic acid, $\mathrm{g} / \mathrm{kg}$ of $\mathrm{DM}$ & 12 & 19 & 11 & 15 & 7 & 10 & 6 & 9 & 25 & 32 & 14 & 19 & 13 & 15 & 2.3 & $* *$ & $* * *$ & \\
\hline Propionic acid, $\mathrm{g} / \mathrm{kg}$ of $\mathrm{DM}$ & 0 & 1 & 0 & 0 & 0 & 0 & 0 & 0 & 0 & 0 & 0 & 0 & 1 & 1 & 0.2 & & * & \\
\hline Butyric acid, $\mathrm{g} / \mathrm{kg}$ of DM & 0 & 1 & 0 & 0 & 0 & 0 & 0 & 0 & 6 & 8 & 0 & 0 & 0 & 0 & 1.1 & & $* * *$ & \\
\hline Ethanol, $\mathrm{g} / \mathrm{kg}$ of DM & 5 & 5 & 6 & 5 & 6 & 5 & 9 & 7 & 5 & 8 & 3 & 5 & 3 & 4 & 0.6 & & $* * *$ & ** \\
\hline Lactic acid:FP, \% & 80 & 78 & 79 & 80 & 77 & 79 & 87 & 87 & 69 & 66 & 82 & 77 & 82 & 78 & 2.5 & & $* * *$ & \\
\hline DM recovery, $\mathrm{g} / \mathrm{kg}$ of DM ensiled & 932 & 898 & 938 & 914 & 934 & 893 & 942 & 889 & 924 & 888 & 940 & 898 & 952 & 900 & 13.0 & $* * *$ & & \\
\hline Aerobic stability, d & 7.0 & 10.0 & 10.0 & 11.0 & 13.0 & 12.5 & 5.0 & 3.5 & 15.0 & 10.5 & 13.5 & 12.0 & 14.0 & 11.0 & 0.89 & & $* * *$ & * \\
\hline Aerobic deterioration, ${ }^{\circ} \mathrm{C}$ & 4 & 2 & 2 & 1 & 1 & 0 & 5 & 18 & 2 & 3 & 2 & 1 & 2 & 1 & 1.5 & & $* * *$ & $* *$ \\
\hline \multicolumn{19}{|l|}{ Harvest 2} \\
\hline Standard of fermentation & 2.0 & 1.0 & 4.0 & 1.0 & 5.0 & 1.3 & 2.0 & 1.0 & 2.0 & 1.0 & 3.7 & 1.0 & 5.0 & 1.0 & 0.25 & $* * *$ & $* * *$ & $* * *$ \\
\hline $\mathrm{DM}, \mathrm{g} / \mathrm{kg}$ & 145 & 143 & 151 & 142 & 155 & 146 & 148 & 142 & 152 & 145 & 156 & 138 & 158 & 147 & 1.9 & $* * *$ & $* *$ & $* *$ \\
\hline $\mathrm{pH}$ & 5.5 & 5.4 & 4.5 & 5.6 & 4.1 & 5.5 & 5.4 & 5.3 & 5.5 & 5.4 & 4.7 & 5.9 & 4.5 & 6.2 & 0.10 & $* * *$ & $* * *$ & $* * *$ \\
\hline $\mathrm{NH}_{3}-\mathrm{N}$ uncorrected, $\mathrm{g} / \mathrm{kg}$ of $\mathrm{N}$ & 238 & 553 & 140 & 473 & 136 & 389 & 198 & 586 & 188 & 573 & 124 & 452 & 99 & 250 & 36.8 & $* * *$ & $* * *$ & $*$ \\
\hline $\mathrm{NH}_{3}-\mathrm{N}$ corrected, $\mathrm{g} / \mathrm{kg}$ of $\mathrm{N}$ & 238 & 553 & 105 & 441 & 67 & 323 & 198 & 586 & 188 & 573 & 95 & 424 & 40 & 187 & 37.6 & $* * *$ & $* * *$ & * \\
\hline $\mathrm{CP}, \mathrm{g} / \mathrm{kg}$ of $\mathrm{DM}$ & 179 & 135 & 199 & 148 & 205 & 166 & 183 & 132 & 183 & 131 & 191 & 148 & 198 & 169 & 4.3 & $* * *$ & $* * *$ & \\
\hline WSC, $\mathrm{g} / \mathrm{kg}$ of $\mathrm{DM}$ & 2 & 1 & 2 & 1 & 3 & 1 & 2 & 0 & 2 & 0 & 1 & 1 & 3 & 2 & 0.2 & $* * *$ & $* * *$ & $*$ \\
\hline Lactic acid, $\mathrm{g} / \mathrm{kg}$ of DM & 11 & 12 & 97 & 11 & 111 & 33 & 13 & 12 & 10 & 11 & 100 & 12 & 116 & 27 & 5.4 & $* * *$ & $* * *$ & $* * *$ \\
\hline Acetic acid, $\mathrm{g} / \mathrm{kg}$ of DM & 75 & 80 & 43 & 67 & 16 & 47 & 76 & 77 & 70 & 76 & 45 & 48 & 19 & 37 & 4.3 & $* * *$ & $* * *$ & $* *$ \\
\hline Propionic acid, $\mathrm{g} / \mathrm{kg}$ of DM & 14 & 24 & 5 & 16 & 0 & 9 & 12 & 27 & 11 & 24 & 7 & 18 & 2 & 5 & 2.0 & $* * *$ & $* * *$ & \\
\hline Butyric acid, g/kg of DM & 16 & 38 & 1 & 41 & 0 & 34 & 9 & 41 & 14 & 43 & 0 & 45 & 0 & 34 & 5.2 & $* * *$ & & \\
\hline Ethanol, $\mathrm{g} / \mathrm{kg}$ of DM & 24 & 2 & 9 & 5 & 13 & 4 & 26 & 2 & 25 & 2 & 6 & 2 & 4 & 15 & 1.7 & $* * *$ & $* * *$ & $* * *$ \\
\hline Lactic acid:FP, \% & 8 & 8 & 63 & 8 & 80 & 26 & 10 & 7 & 8 & 7 & 64 & 10 & 83 & 22 & 3.8 & $* * *$ & $* * *$ & $* * *$ \\
\hline DM recovery, $\mathrm{g} / \mathrm{kg}$ of DM ensiled & 843 & 813 & 885 & 871 & 906 & 903 & 879 & 806 & 883 & 817 & 917 & 814 & 911 & 906 & 16.2 & $* * *$ & $* * *$ & $*$ \\
\hline Aerobic stability, d & 6.5 & $>10.0$ & 5.0 & 7.5 & 6.0 & 7.0 & 5.0 & $>10.0$ & 5.0 & $>10.0$ & 6.5 & 6.5 & 8.0 & 4.0 & & - & -- & \\
\hline SD & $(0.71)$ & $(0.00)$ & $(0.00)$ & $(0.71)$ & $(0.00)$ & $(0.00)$ & $(0.00)$ & $(0.00)$ & $(0.00)$ & $(0.00)$ & $(0.71)$ & $(0.71)$ & $(0.00)$ & $(0.00)$ & & & & \\
\hline $\begin{array}{l}\text { Aerobic deterioration, }{ }^{\circ} \mathrm{C} \\
\text { SD }\end{array}$ & $\begin{array}{l}2 \\
(1.0)\end{array}$ & $\begin{array}{l}0 \\
(0.0)\end{array}$ & $\begin{array}{l}4 \\
(0.1)\end{array}$ & $(0.9)$ & $\begin{array}{l}2 \\
(1.6)\end{array}$ & $\begin{array}{l}1 \\
(0.9)\end{array}$ & $\begin{array}{l}7 \\
(3.7)\end{array}$ & $\begin{array}{l}0 \\
(0.0)\end{array}$ & $\begin{array}{l}7 \\
(1.4)\end{array}$ & $\begin{array}{l}0 \\
(0.0)\end{array}$ & $\begin{array}{l}0 \\
(0.5)\end{array}$ & $\begin{array}{l}2 \\
(1.4)\end{array}$ & $\begin{array}{l}1 \\
(1.1)\end{array}$ & $\begin{array}{l}18 \\
(7.4)\end{array}$ & & - & -- & \\
\hline \multicolumn{19}{|l|}{ Harvest 3} \\
\hline Standard of fermentation & 5.0 & 5.0 & 5.0 & 5.0 & 5.0 & 5.0 & 5.0 & 5.0 & 4.7 & 5.0 & 4.3 & 4.7 & 3.0 & 4.0 & 0.15 & $* *$ & $* * *$ & $*$ \\
\hline $\mathrm{DM}, \mathrm{g} / \mathrm{kg}$ & 249 & 263 & 254 & 262 & 248 & 264 & 253 & 261 & 250 & 262 & 249 & 261 & 251 & 258 & 2.9 & $* * *$ & & \\
\hline $\mathrm{pH}$ & 4.2 & 4.3 & 4.3 & 4.2 & 4.2 & 4.2 & 4.2 & 4.3 & 4.2 & 4.3 & 4.4 & 4.4 & 4.5 & 4.5 & 0.05 & & $* * *$ & \\
\hline $\mathrm{NH}_{3}-\mathrm{N}$ uncorrected, $\mathrm{g} / \mathrm{kg}$ of $\mathrm{N}$ & 89 & 93 & 101 & 93 & 116 & 108 & 84 & 89 & 87 & 89 & 91 & 88 & 98 & 99 & 2.7 & & $* * *$ & \\
\hline $\mathrm{NH}_{3}-\mathrm{N}$ corrected, $\mathrm{g} / \mathrm{kg}$ of $\mathrm{N}$ & 89 & 93 & 78 & 70 & 67 & 62 & 84 & 89 & 87 & 89 & 72 & 69 & 61 & 60 & 2.6 & & $* * *$ & \\
\hline $\mathrm{CP}, \mathrm{g} / \mathrm{kg}$ of $\mathrm{DM}$ & 167 & 158 & 171 & 165 & 168 & 167 & 164 & 160 & 171 & 161 & 175 & 167 & 175 & 167 & 1.8 & $* * *$ & $* * *$ & \\
\hline WSC, $\mathrm{g} / \mathrm{kg}$ of DM & 2 & 2 & 3 & 2 & 7 & 8 & 3 & 2 & 2 & 2 & 2 & 2 & 2 & 5 & 0.9 & & $* * *$ & \\
\hline Lactic acid, $\mathrm{g} / \mathrm{kg}$ of DM & 130 & 117 & 109 & 109 & 99 & 92 & 124 & 120 & 122 & 115 & 106 & 116 & 95 & 96 & 5.7 & & $* * *$ & \\
\hline Acetic acid, $\mathrm{g} / \mathrm{kg}$ of $\mathrm{DM}$ & 23 & 25 & 21 & 19 & 16 & 15 & 16 & 22 & 29 & 24 & 31 & 30 & 43 & 35 & 1.4 & & $* * *$ & ** \\
\hline Propionic acid, $\mathrm{g} / \mathrm{kg}$ of DM & 1 & 1 & 0 & 1 & 0 & 0 & 0 & 1 & 1 & 1 & 2 & 1 & 2 & 2 & 0.1 & & $* * *$ & $* *$ \\
\hline Butyric acid, $\mathrm{g} / \mathrm{kg}$ of DM & 2 & 1 & 1 & 0 & 0 & 0 & 1 & 1 & 1 & 0 & 1 & 0 & 8 & 3 & 0.7 & $* *$ & $* * *$ & $*$ \\
\hline
\end{tabular}




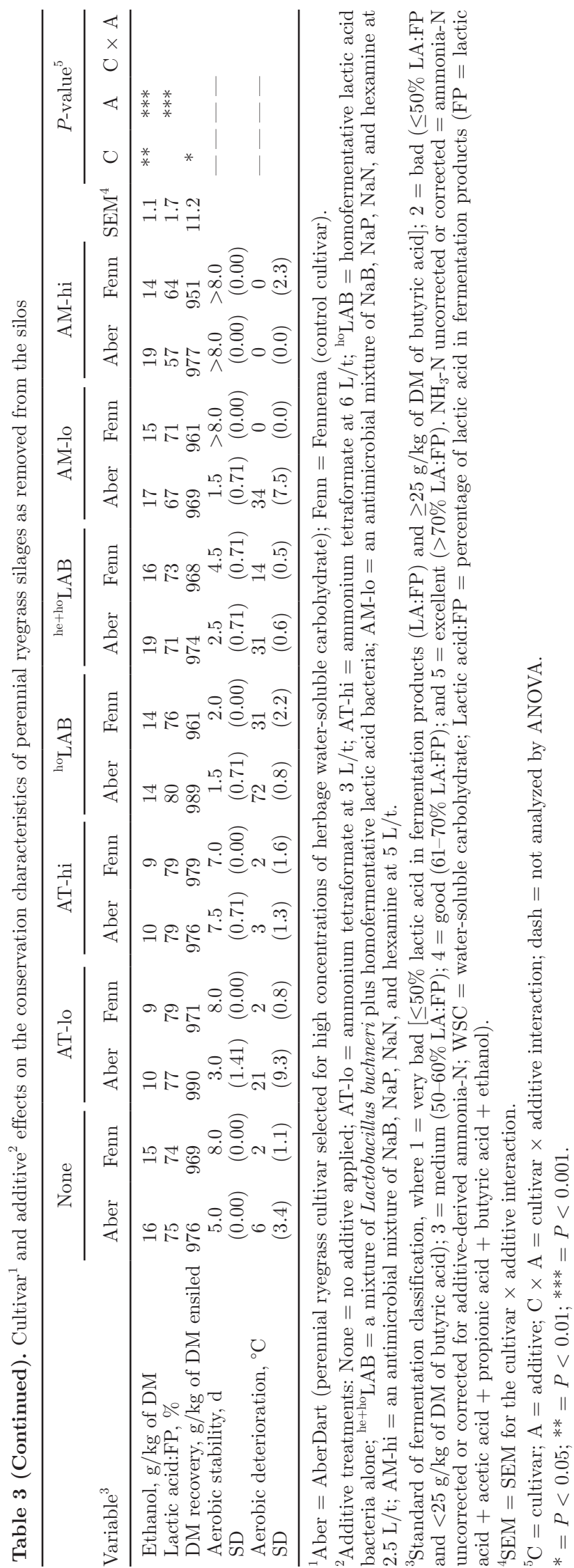

$\mathrm{kg}$ of DM). All harvests were relatively stable under the aerobic test conditions. Aerobic stability values ranged from 5 to $>10 \mathrm{~d}$ and aerobic deterioration from 0 to $6^{\circ} \mathrm{C}$.

Additive AT-lo. The AT-lo (ammonium tetraformate at $3 \mathrm{~L} / \mathrm{t}$ ) additive produced silages classed as excellent $(\mathrm{n}=4)$, good $(\mathrm{n}=1)$, or very bad $(\mathrm{n}=$ 1) standard of fermentation depending on cultivarharvest combination. Treatment AT-lo applied to AberDart and Fennema from harvests 1 and 3 produced lactic acid-dominant silages ( $\geq 77 \%$ LA:FP) of excellent standard of fermentation with relatively low $\mathrm{pH}(\leq 4.5)$ and concentrations of ammonia- $\mathrm{N}$ (corrected; $<78 \mathrm{~g} /$ $\mathrm{kg}$ of $\mathrm{N})$, butyric acid $(\leq 1 \mathrm{~g} / \mathrm{kg}$ of $\mathrm{DM})$, and ethanol $(\leq 10 \mathrm{~g} / \mathrm{kg}$ of DM). There were no differences between the AT-lo and untreated silages from harvests 1 and 3 in the standard of fermentation classification, although AT-lo tended to restrict the lactic acid fermentation and reduce proteolysis, resulting in silages with lower concentrations of lactic acid and ammonia-N (corrected) than the untreated control.

Treatment AT-lo applied to harvest 2 produced silages of good (AberDart) or very bad (Fennema) standard of fermentation depending on cultivar. From AberDart, AT-lo improved the standard of fermentation classification from bad to good compared with the untreated control as a result of decreasing $\mathrm{pH}$ to 4.5 and the concentrations of ammonia-N (corrected) to $105 \mathrm{~g} / \mathrm{kg}$ of DM, acetic acid to $43 \mathrm{~g} / \mathrm{kg}$ of DM, and ethanol to $9 \mathrm{~g} / \mathrm{kg}$ of $\mathrm{DM}$ and increasing lactic acid concentration to $97 \mathrm{~g} / \mathrm{kg}$ of DM. From Fennema, there were no differences between the AT-lo and untreated silages in the standard of fermentation classification, $\mathrm{pH}(\geq 5.4)$, and concentrations of lactic acid $(\leq 12 \mathrm{~g} / \mathrm{kg}$ of DM), butyric acid ( $\geq 38 \mathrm{~g} / \mathrm{kg}$ of $\mathrm{DM})$, and ethanol $(\leq 5 \mathrm{~g} / \mathrm{kg}$ of DM).

From harvest 1, the AT-lo silages had 15 to $16 \mathrm{~g} / \mathrm{kg}$ of DM higher concentrations of residual WSC than the untreated silages depending on cultivar. From harvests 2 and 3, there was no difference between the AT-lo and untreated silages in residual WSC concentration, with both treatments containing trace quantities of $3 \mathrm{~g} / \mathrm{kg}$ of DM or less.

The aerobic stability of the AT-lo silages was longer $(\mathrm{n}=1)$ or not different $(\mathrm{n}=5)$ from the untreated control depending on cultivar-harvest combination. However, there were consistently no differences between the AT-lo and untreated silages in aerobic deterioration across all cultivar-harvest combinations. The more aerobically stable AT-lo silage did not differ from the untreated control in the standard of fermentation classification.

Additive $\boldsymbol{A T}$-hi. The AT-hi (ammonium tetraformate at $6 \mathrm{~L} / \mathrm{t}$ ) additive produced silages classed as 
Table 4. Cultivar and additive effects on the number of silages per level of 7 key variables of silage quality ${ }^{1}$

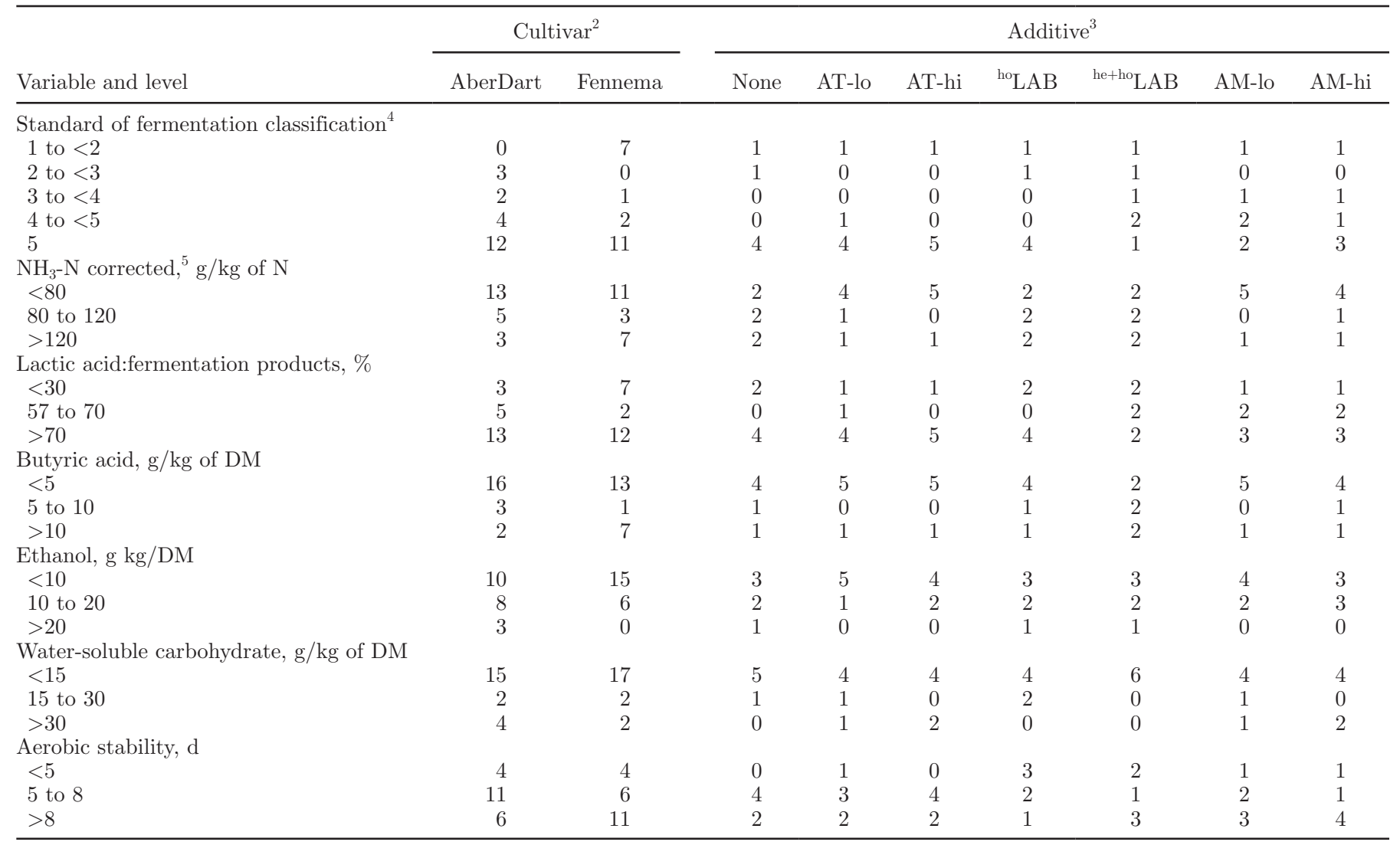

${ }^{1}$ Data for cultivar represents the cumulative effects of each cultivar across all additive-harvest combinations ( $\mathrm{n}=21$ silages). Data for additive represents the cumulative effects of each additive across all cultivar-harvest combinations $(\mathrm{n}=6$ silages).

${ }^{2}$ AberDart $=$ perennial ryegrass cultivar selected for high concentrations of herbage water-soluble carbohydrate; Fennema $=$ control cultivar.

${ }^{3}$ Additive treatments: None $=$ no additive applied; AT-lo $=$ ammonium tetraformate at $3 \mathrm{~L} / \mathrm{t}$; AT-hi $=$ ammonium tetraformate at $6 \mathrm{~L} / \mathrm{t}$;

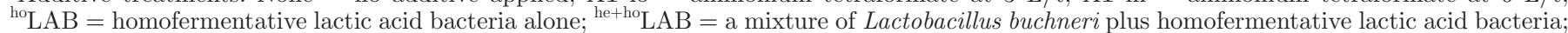
$\mathrm{AM}-\mathrm{lo}=$ an antimicrobial mixture of $\mathrm{NaB}, \mathrm{NaP}, \mathrm{NaN}$, and hexamine at $2.5 \mathrm{~L} / \mathrm{t}$; AM-hi $=$ an antimicrobial mixture of NaB, NaP, NaN, and hexamine at $5 \mathrm{~L} / \mathrm{t}$.

${ }^{4}$ Standard of fermentation classification, where $1=$ very bad $[\leq 50 \%$ lactic acid in fermentation products $(\mathrm{LA}: \mathrm{FP})$ and $\geq 25 \mathrm{~g} / \mathrm{kg}$ of DM of butyric acid]; $2=\operatorname{bad}(\leq 50 \% \mathrm{LA}: \mathrm{FP}$ and $<25 \mathrm{~g} / \mathrm{kg}$ of DM of butyric acid); $3=$ medium $(50-60 \% \mathrm{LA}: \mathrm{FP}) ; 4=\operatorname{good}(61-70 \% \mathrm{LA}: \mathrm{FP}) ;$ and $5=$ excellent $(>70 \%$ LA:FP).

${ }^{5} \mathrm{NH}_{3}-\mathrm{N}$ corrected $=$ ammonia- $\mathrm{N}$ corrected for additive-derived ammonia-N.

excellent $(\mathrm{n}=5)$ or bad to very bad $(\mathrm{n}=1)$ standard of fermentation depending on cultivar-harvest combination. Treatment AT-hi applied to AberDart and Fennema from harvests 1 and 3 produced lactic aciddominant silages ( $\geq 77 \%$ LA:FP) of excellent standard of fermentation with relatively low $\mathrm{pH}(\leq 4.5)$ and concentrations of ammonia-N (corrected; $\leq 67 \mathrm{~g} / \mathrm{kg}$ of $\mathrm{N}$ ), butyric acid $(0 \mathrm{~g} / \mathrm{kg}$ of DM), and ethanol $(\leq 10 \mathrm{~g} / \mathrm{kg}$ of $\mathrm{DM})$. There were no differences between the AT-hi and untreated silages from harvests 1 and 3 in the standard of fermentation classification, although AT-hi tended to restrict the lactic acid fermentation and reduce proteolysis, resulting in silages with lower concentrations of lactic acid and ammonia-N (corrected) than the untreated control.
Treatment AT-hi applied to harvest 2 produced silages of excellent (AberDart) or bad to very bad (Fennema) standard of fermentation depending on cultivar. From AberDart, AT-hi improved the standard of fermentation classification from bad to excellent compared with the untreated control as a result of decreasing $\mathrm{pH}$ to 4.1 and the concentrations of ammonia- $\mathrm{N}$ (corrected) to 67 $\mathrm{g} / \mathrm{kg}$ of DM, acetic acid to $16 \mathrm{~g} / \mathrm{kg}$ of DM, and ethanol to $13 \mathrm{~g} / \mathrm{kg}$ of DM and increasing lactic acid concentration to $111 \mathrm{~g} / \mathrm{kg}$ of DM. From Fennema, there were no differences between the AT-hi and untreated silages in the standard of fermentation classification, $\mathrm{pH}(\geq 5.4)$, and concentrations of butyric acid $(\geq 34 \mathrm{~g} / \mathrm{kg}$ of DM) and ethanol $(\leq 4 \mathrm{~g} / \mathrm{kg}$ of DM) and, taken in the context of very badly fermented silage, only minor differences 
in concentrations of ammonia- $\mathrm{N}$ (corrected; $\geq 323 \mathrm{~g} / \mathrm{kg}$ of DM), lactic acid ( $\leq 33 \mathrm{~g} / \mathrm{kg}$ of $\mathrm{DM})$, and acid acetic $(\geq 47 \mathrm{~g} / \mathrm{kg}$ of DM).

From harvests 1 and 3, the AT-hi silages had higher concentrations of residual WSC than the untreated silages. The difference ranged from 30 to $32 \mathrm{~g} / \mathrm{kg}$ of DM for harvest 1 and 5 to $6 \mathrm{~g} / \mathrm{kg}$ of $\mathrm{DM}$ for harvest 3, depending on cultivar. From harvest 2, there were no differences between the AT-hi and untreated silages in residual WSC concentration, with both treatments containing concentrations of $3 \mathrm{~g} / \mathrm{kg}$ of DM or less.

The aerobic stability of the AT-hi silages was longer $(\mathrm{n}=1)$, shorter $(\mathrm{n}=2 ; P<0.001)$, or not different (n $=3$ ) from the untreated control depending on cultivarharvest combination. However, there were consistently no differences between the AT-hi and untreated silages in aerobic deterioration across all cultivar-harvest combinations. The AT-hi and untreated silages that differed in aerobic stability did not differ in the standard of fermentation classification.

Additive ${ }^{\text {ho }} \boldsymbol{L} \boldsymbol{A} \boldsymbol{B}$. The ${ }^{\text {ho }} \mathrm{LAB}$ (homofermentative LAB alone) additive produced silages classed as excellent $(\mathrm{n}=4)$, bad $(\mathrm{n}=1)$, or very bad $(\mathrm{n}=1)$ standard of fermentation depending on cultivar-harvest combination. Treatment ${ }^{\text {ho }} \mathrm{LAB}$ applied to AberDart and Fennema from harvests 1 and 3 produced lactic acid- dominant silages $(\geq 76 \%$ LA:FP) of excellent standard of fermentation with relatively low $\mathrm{pH}(\leq 4.3)$ and concentrations of ammonia- $\mathrm{N}$ (corrected; $\leq 89 \mathrm{~g} /$ $\mathrm{kg}$ of $\mathrm{N})$, butyric acid $(\leq 1 \mathrm{~g} / \mathrm{kg}$ of $\mathrm{DM})$, and ethanol $(\leq 14 \mathrm{~g} / \mathrm{kg}$ of DM). There were no differences between the ${ }^{\text {ho }} \mathrm{LAB}$ and untreated silages from harvests 1 and 3 in the standard of fermentation classification. However, from harvest $1,{ }^{\text {ho }} \mathrm{LAB}$ tended to increase the lactic acid fermentation and reduce proteolysis compared with the untreated control, resulting in silages with lower $\mathrm{pH}$ and concentrations of ammonia- $\mathrm{N}$ (corrected) and acetic acid and higher lactic acid concentration. In contrast, from harvest 3 , inoculation with ${ }^{\text {ho }} \mathrm{LAB}$ had no effect on silage $\mathrm{pH}$ and concentrations of ammonia- $\mathrm{N}$ (corrected) and lactic acid and, depending on cultivar, little or no effect on acetic acid concentration compared with the untreated control.

Treatment ${ }^{\text {ho }} \mathrm{LAB}$ applied to harvest 2 produced silages of bad (AberDart) or very bad (Fennema) standard of fermentation depending on cultivar. These silages had high $\mathrm{pH}(\geq 5.3)$, low lactic acid concentrations $(\leq 13 \mathrm{~g} / \mathrm{kg}$ of DM), high concentrations of ammonia-N (corrected; $\geq 198 \mathrm{~g} / \mathrm{kg}$ of DM), acetic acid $(\geq 76 \mathrm{~g} / \mathrm{kg}$ of DM), and butyric acid ( $\geq 9 \mathrm{~g} / \mathrm{kg}$ of $\mathrm{DM})$, and low to high concentrations of ethanol $(2-26 \mathrm{~g} / \mathrm{kg}$ of $\mathrm{DM})$. The very badly fermented silages had 3.0 and 4.6 times higher concentrations of ammonia- $\mathrm{N}$ (corrected) and butyric acid, respectively, than the badly fermented silages. There were no differences between the ${ }^{\text {ho }} \mathrm{LAB}$ and untreated silages from harvest 2 in the standard of fermentation classification, $\mathrm{pH}$, and concentrations of ammonia-N (corrected), lactic acid, acetic acid, butyric acid, and ethanol.

The ${ }^{\text {ho }} \mathrm{LAB}$ and untreated silages did not differ in residual WSC concentration across all cultivar-harvest combinations. However, the ${ }^{\text {ho }} \mathrm{LAB}$ and the untreated control differed $(P<0.05$ or less $)$ in aerobic stability, aerobic deterioration, or both for 3 cultivar-harvest combinations, with ${ }^{\text {ho }} \mathrm{LAB}$ less aerobically stable, undergoing more aerobic deterioration, or both than the untreated control. The magnitude of the difference was large, with differences in aerobic stability ranging from 6.0 to $6.5 \mathrm{~d}$ and aerobic deterioration from 16 to $66^{\circ} \mathrm{C}$. The ${ }^{\text {ho }} \mathrm{LAB}$ and untreated silages that differed in aerobic stability or deterioration did not differ in the standard of fermentation classification.

Additive ${ }^{\text {he }+ \text { ho }} \boldsymbol{L} \boldsymbol{A} \boldsymbol{B}$. The ${ }^{\text {he+ho }} \mathrm{LAB}$ (L. buchneri plus homofermentative LAB) additive produced silages classed as excellent $(n=2)$, good to excellent $(n=1)$, $\operatorname{good}(\mathrm{n}=1)$, medium to good $(\mathrm{n}=1)$, bad $(\mathrm{n}=1)$, or very bad $(\mathrm{n}=1)$ standard of fermentation depending on cultivar-harvest combination. Treatment ${ }^{\text {he+ho }} \mathrm{LAB}$ applied to AberDart and Fennema from harvest 3 produced lactic acid-dominant silages $(\geq 71 \%$ LA:FP) of excellent or good to excellent standard of fermentation with relatively low $\mathrm{pH}(\leq 4.3)$ and concentrations of ammonia-N (corrected; $\leq 89 \mathrm{~g} / \mathrm{kg}$ of $\mathrm{N}$ ), butyric acid $(\leq 1 \mathrm{~g} / \mathrm{kg}$ of $\mathrm{DM})$, and ethanol $(\leq 19 \mathrm{~g} / \mathrm{kg}$ of $\mathrm{DM})$. There were no differences among the he+ho $\mathrm{LAB},{ }^{\text {ho }} \mathrm{LAB}$, and untreated silages from harvest 3 in the standard of fermentation classification, $\mathrm{pH}$, and concentrations of ammonia-N (corrected), lactic acid, and butyric acid, and little or no differences in ethanol concentration. However, the ${ }^{\text {he+ho }} \mathrm{LAB}$ additive had an inconsistent effect on acetic acid concentration depending on cultivar. From AberDart at harvest 3, the he+ho LAB silages had 6 and $13 \mathrm{~g} / \mathrm{kg}$ of DM higher concentrations of acetic acid than the untreated and ho ${ }^{2} \mathrm{AB}$ silages, respectively. From Fennema at harvest 3, there were no differences among the ${ }^{\text {he+ho }} \mathrm{LAB},{ }^{\text {ho }} \mathrm{LAB}$, and untreated silages in acetic acid concentration.

Treatment ${ }^{\text {he+ho }} \mathrm{LAB}$ applied to harvest 1 produced lactic acid-dominant silages ( $\geq 66 \%$ LA:FP) of good or medium to good standard of fermentation with relatively low $\mathrm{pH}$ (4.3) and concentrations of ammonia-N (corrected; $\leq 67 \mathrm{~g} / \mathrm{kg}$ of $\mathrm{N}$ ) and ethanol $(8 \mathrm{~g} / \mathrm{kg}$ of DM). However, the he+ho LAB silages had a lower standard of fermentation classification than the untreated control and ho $\mathrm{LAB}$ additive, primarily as a result of he+ho $\mathrm{LAB}$ increasing the concentration of acetic acid to $\geq 25 \mathrm{~g} / \mathrm{kg}$ of DM and butyric acid to $\geq 6 \mathrm{~g} / \mathrm{kg}$ of DM. 
Treatment ${ }^{\text {he }+ \text { ho }}$ LAB applied to harvest 2 produced silages of bad (AberDart) or very bad (Fennema) standard of fermentation depending on cultivar. These silages had high $\mathrm{pH}(\geq 5.4)$, low concentrations of lactic acid $(\leq 11 \mathrm{~g} / \mathrm{kg}$ of $\mathrm{DM})$, high concentrations of ammonia-N (corrected; $\geq 188 \mathrm{~g} / \mathrm{kg}$ of $\mathrm{DM}$ ), acetic acid $(\geq 70 \mathrm{~g} / \mathrm{kg}$ of DM), and butyric acid ( $\geq 14 \mathrm{~g} / \mathrm{kg}$ of DM), and low to high concentrations of ethanol $(2-25 \mathrm{~g} / \mathrm{kg}$ of DM). The very badly fermented silage had 3.0 and 3.1 times higher ammonia-N (corrected) and butyric acid concentrations, respectively, than the badly fermented silage. There were no differences among the ${ }^{\text {he }+ \text { ho }} \mathrm{LAB},{ }^{\text {ho }} \mathrm{LAB}$, and untreated silages from harvest 2 in the standard of fermentation classification, $\mathrm{pH}$, and concentrations of ammonia- $\mathrm{N}$ (corrected), lactic acid, acetic acid, butyric acid, and ethanol.

From harvest 1 , the ${ }^{\text {he+ho }}$ LAB silages had lower concentrations of residual WSC than the untreated and ${ }^{\text {ho }} \mathrm{LAB}$ silages. The difference between additive treatments ranged from 5 to $7 \mathrm{~g} / \mathrm{kg}$ of DM for the Fennema silages and 21 to $24 \mathrm{~g} / \mathrm{kg}$ of DM for the AberDart silages. From harvests 2 and 3, there were no differences among the he+ho $\mathrm{LAB},{ }^{\text {ho }} \mathrm{LAB}$, and untreated silages in residual WSC concentration across both cultivars.

The ${ }^{\text {he+ho }} \mathrm{LAB}$ silages differed $(P<0.05$ or less) from the untreated and ${ }^{\text {ho }} \mathrm{LAB}$ silages in aerobic stability, aerobic deterioration, or both for 4 cultivar-harvest combinations. The ${ }^{\text {he+ho }} \mathrm{LAB}$ silages had a longer duration of aerobic stability than the untreated control for 1 cultivar-harvest combination but underwent more aerobic deterioration than the untreated control for another 3 cultivar-harvest combinations. Compared with ${ }^{\text {ho }} \mathrm{LAB}$, the ${ }^{\text {he }+ \text { ho }} \mathrm{LAB}$ silages had a longer duration of aerobic stability, underwent less aerobic deterioration, or both for 4 cultivar-harvest combinations. In most cases $(60 \%)$, the increase in aerobic stability or reduction in aerobic deterioration with ${ }^{\text {he+ho }}{ }^{\mathrm{LAB}}$ treatment was associated with a lower standard of fermentation classification.

Additive $\boldsymbol{A} \boldsymbol{M}$-lo. The AM-lo (mixture of NaB, $\mathrm{NaP}, \mathrm{NaN}$, and hexamine at $2.5 \mathrm{~L} / \mathrm{t}$ ) additive produced silages classed as excellent $(\mathrm{n}=2)$, good to excellent (n $=2)$, medium to good $(\mathrm{n}=1)$, or bad $(\mathrm{n}=1)$ standard of fermentation depending on cultivar-harvest combination. Treatment AM-lo applied to AberDart and Fennema from harvest 1 produced lactic acid-dominant silages ( $\geq 77 \%$ LA:FP) of excellent standard of fermentation with relatively low $\mathrm{pH}(4.4)$ and concentrations of ammonia-N (corrected; $\leq 60 \mathrm{~g} / \mathrm{kg}$ of $\mathrm{N}$ ), butyric acid $(0 \mathrm{~g} / \mathrm{kg}$ of DM), and ethanol $(\leq 5 \mathrm{~g} / \mathrm{kg}$ of DM). There were no differences between the AM-lo and untreated silages from harvest 1 in the standard of fermentation classification and concentrations of lactic acid, acetic acid, and butyric acid, and only minor differences in
$\mathrm{pH}$ and concentrations of ammonia- $\mathrm{N}$ (corrected) and ethanol.

Treatment AM-lo applied to harvest 3 produced lactic acid-dominant silages ( $\geq 67 \%$ LA:FP) of good to excellent standard of fermentation with relatively low concentrations of ammonia-N (corrected; $\leq 72 \mathrm{~g} / \mathrm{kg}$ of $\mathrm{N})$, butyric acid ( $\leq 1 \mathrm{~g} / \mathrm{kg}$ of DM), and ethanol $(\leq 17 \mathrm{~g} /$ $\mathrm{kg}$ of DM). However, the AM-lo silages had higher $\mathrm{pH}$ (4.4) and acetic acid concentrations (30 to $31 \mathrm{~g} / \mathrm{kg}$ of $\mathrm{DM})$ and lower lactic acid concentrations $(\leq 116 \mathrm{~g} / \mathrm{kg}$ of DM) than the untreated control. The differences between AM-lo and the untreated control were greater for AberDart than for Fennema, with the result that the AM-lo silage from AberDart had a lower standard of fermentation classification than the untreated control.

Treatment AM-lo applied to harvest 2 produced silages of medium to good (AberDart) or very bad (Fennema) standard of fermentation depending on cultivar. From AberDart, AM-lo improved the standard of fermentation classification from bad to medium-togood compared with the untreated control as a result of decreasing $\mathrm{pH}$ to 4.7 and the concentrations of ammonia-N (corrected) to $95 \mathrm{~g} / \mathrm{kg}$ of DM, acetic acid to $45 \mathrm{~g} / \mathrm{kg}$ of DM, and ethanol to $6 \mathrm{~g} / \mathrm{kg}$ of DM and increasing lactic acid concentration to $100 \mathrm{~g} / \mathrm{kg}$ of DM. From Fennema, there were no differences between the AM-lo and untreated silages in the standard of fermentation classification and concentrations of ammonia- $\mathrm{N}$ (corrected; $\geq 424 \mathrm{~g} / \mathrm{kg}$ of DM), lactic acid $(12 \mathrm{~g} / \mathrm{kg}$ of $\mathrm{DM})$, butyric acid $(\geq 38 \mathrm{~g} / \mathrm{kg}$ of $\mathrm{DM})$, and ethanol (2 $\mathrm{g} / \mathrm{kg}$ of DM) and, taken in the context of very badly fermented silage, only minor differences in $\mathrm{pH}(\geq 5.4)$ and acetic acid ( $\leq 80 \mathrm{~g} / \mathrm{kg}$ of DM) concentration.

The AM-lo and untreated silages differed in residual WSC concentration for only 1 cultivar-harvest combination. From Fennema at harvest 1, AM-lo had $8 \mathrm{~g} / \mathrm{kg}$ of DM higher concentration of residual WSC than the untreated control.

Treatment AM-lo differed $(P<0.05$ or less) from the untreated control in aerobic stability or aerobic deterioration for 3 cultivar-harvest combinations. The AM-lo silages had a longer duration of aerobic stability than the untreated control for 2 cultivar-harvest combinations but underwent more aerobic deterioration than the untreated control for 1 cultivar-harvest combination. The standard of fermentation classification of the more aerobically stable AM-lo silages was lower or not different from the untreated control depending on cultivar-harvest combination.

Additive A $\boldsymbol{M}$-hi . The AM-hi (mixture of NaB, NaP, $\mathrm{NaN}$, and hexamine at $5 \mathrm{~L} / \mathrm{t}$ ) additive produced silages classed as excellent $(\mathrm{n}=3)$, good $(\mathrm{n}=1)$, medium $(\mathrm{n}$ $=1)$, or very bad $(n=1)$ standard of fermentation depending on cultivar-harvest combination. Treatment 
AM-hi applied to AberDart and Fennema from harvest 1 produced lactic acid-dominant silages ( $\geq 78 \%$ LA:FP) of excellent standard of fermentation with relatively low $\mathrm{pH}$ (4.5) and concentrations of ammonia-N (corrected; $\leq 49 \mathrm{~g} / \mathrm{kg}$ of $\mathrm{N})$, butyric acid $(0 \mathrm{~g} / \mathrm{kg}$ of $\mathrm{DM})$, and ethanol $(\leq 4 \mathrm{~g} / \mathrm{kg}$ of $\mathrm{DM})$. There were no differences between the AM-hi and untreated silages from harvest 1 in the standard of fermentation classification, although AT-hi tended to restrict the lactic acid fermentation and reduce proteolysis, resulting in silages with lower concentrations of lactic acid and ammonia$\mathrm{N}$ (corrected) than the untreated control.

Treatment AM-hi applied to harvest 2 produced silages of excellent (AberDart) or very bad (Fennema) standard of fermentation depending on cultivar. From AberDart, AM-hi improved the standard of fermentation classification from bad to excellent compared with the untreated control as a result of decreasing $\mathrm{pH}$ to 4.5 and the concentrations of ammonia- $\mathrm{N}$ (corrected) to 40 $\mathrm{g} / \mathrm{kg}$ of DM, acetic acid to $19 \mathrm{~g} / \mathrm{kg}$ of DM, and ethanol to $4 \mathrm{~g} / \mathrm{kg}$ of DM and increasing lactic acid concentration to $116 \mathrm{~g} / \mathrm{kg}$ of DM. From Fennema, the AM-hi and untreated silages did not differ in the standard of fermentation classification and, although differences between the 2 treatments in fermentation characteristics were often large and statistically significant, they were biologically unimportant taken in the context of both additive treatments producing silage with $\mathrm{pH} \geq 5.4$ and concentrations of ammonia $\mathrm{N}$ (corrected) $\geq 187 \mathrm{~g} / \mathrm{kg}$ of $\mathrm{N}$ and butyric acid $\geq 34 \mathrm{~g} / \mathrm{kg}$ of DM.

Treatment AM-hi applied to AberDart and Fennema at harvest 3 produced silages of medium (AberDart) or good (Fennema) standard of fermentation, with relatively low concentrations of ammonia-N (corrected; $\leq 61$ $\mathrm{g} / \mathrm{kg}$ of DM) and ethanol ( $\leq 19 \mathrm{~g} / \mathrm{kg}$ of DM). However, the AM-hi silages from harvest 3 had a lower standard of fermentation classification than the untreated control, primarily as a result of AM-hi decreasing LA:FP to $\leq 64 \%$, increasing the concentrations of acetic acid to $\geq 35 \mathrm{~g} / \mathrm{kg}$ of DM and butyric acid to $\geq 3 \mathrm{~g} / \mathrm{kg}$ of DM, and increasing $\mathrm{pH}$ to 4.5 .

From harvest 1, the AM-hi silages had 13 to $22 \mathrm{~g} / \mathrm{kg}$ of DM higher concentrations of residual WSC than the untreated silages depending on cultivar. From harvests 2 and 3, there was no difference between the AM-hi and untreated silages in residual WSC concentration, with both treatments containing concentrations of $5 \mathrm{~g} / \mathrm{kg}$ of DM or less.

Treatment AM-hi differed $(P<0.05$ or less $)$ from the untreated control in aerobic stability for 3 cultivarharvest combinations. The AM-lo silages had a longer duration of aerobic stability than the untreated control for 2 cultivar-harvest combinations and a shorter duration of aerobic stability for 1 cultivar-harvest combina- tion. Corresponding differences in aerobic deterioration were nonsignificant. The standard of fermentation classification of the more aerobically stable AM-hi silages was lower or not different from the untreated control depending on cultivar-harvest combination.

Cultivar. From harvests 1 and 3, cultivar had a relatively minor and mostly nonsignificant effect on the fermentation characteristics. Accordingly, AberDart and Fennema differed in the standard of fermentation classification for only 1 out of 14 additive-harvest combinations. In contrast, cultivar had a large and often significant effect on the fermentation characteristics of silages made from harvest 2. From harvest 2, the AberDart silages had a consistently higher standard of fermentation classification than Fennema, primarily because of consistently lower concentrations of ammonia$\mathrm{N}$ (corrected) and butyric acid, and often lower $\mathrm{pH}$ and higher lactic acid concentration depending on additive treatment.

From harvest 1, AberDart had higher concentrations of residual WSC than Fennema for most (6 out of 7) additive treatments. The difference ranged from 7 to $18 \mathrm{~g} / \mathrm{kg}$ of DM around an overall mean increase of 14 $\mathrm{g} / \mathrm{kg}$ of DM of residual WSC. There was no difference between cultivars treated with ${ }^{\text {he+ho }} \mathrm{LAB}$ at harvest 1 in residual WSC concentration. From harvests 2 and 3, differences between cultivars in residual WSC concentration were small $(\leq 3 \mathrm{~g} / \mathrm{kg}$ of $\mathrm{DM})$ and nonsignificant for most additive-harvest combinations.

Cultivars differed $(P<0.05$ or less $)$ in aerobic stability or deterioration for 13 out of 28 additive-harvest combinations. AberDart had a longer duration of aerobic stability or underwent less aerobic deterioration than Fennema for 8 additive-harvest combinations. Ensiled untreated, the AberDart silages were less aerobically stable than Fennema across all harvests, although the difference was not always significant.

\section{DISCUSSION}

This experiment was conducted in a cool-temperate maritime climate were weather conditions are not always ideal for field wilting. Wilting under poor drying conditions may result in little or no increase in DM concentration and substantial field losses of WSC (Rotz and Muck, 1994). Differences among harvests in herbage chemical composition at ensiling, particularly in DM and WSC concentrations, and in the corresponding untreated silages were substantial, reflecting the variable weather conditions during wilting. These differences confirmed that each harvest was distinctly different and offered a unique test for the additives. Within harvests, there were lesser differences between cultivars. The challenge to the additives was to (1) secure a medium 
or preferably higher standard of fermentation, (2) enhance residual WSC, and (3) protect aerobic stability across all cultivar-harvest combinations.

\section{Ammonium Tetraformate and Homofermentative LAB}

Ammonium tetraformate and inoculants of homofermentative LAB are popular silage additives. Their inclusion in this study was necessary to establish the standards against which ${ }^{\text {he+ho }} \mathrm{LAB}$, AM-lo, and AM-hi would be judged. The effects of AT-lo, AT-hi, and hoLAB were consistent with previous findings (Woolford, 1984; McDonald et al., 1991; Kung et al., 2003). Judged on the 3 criteria described above, AT-hi was the most effective and ${ }^{\text {ho }} \mathrm{LAB}$ the least effective of these 3 additives, under the prevailing test conditions. Treatment with AT-hi produced, on average, more silages of higher standard of fermentation classification and residual WSC concentration and better aerobic stability than either AT-lo or ${ }^{\text {ho }} \mathrm{LAB}$. The positive effects of AT-hi on silage fermentation and residual WSC concentration may be attributed to a restriction in microbial activity, an increase in the lactic acid fermentation, or a combination of both. During ensiling, ammonium tetraformate quickly releases formic acid and ammonia (Kung et al., 2003). The beneficial effect of AT-hi on aerobic stability may caused by the strong antibacterial properties of formic acid (Crawshaw et al., 1980) and the fungicidal and bactericidal properties of ammonia (Muck and Bolsen, 1991). However, considering the high ratio of formic acid to ammonia in ammonium tetraformate, the effects of AT-hi on aerobic stability may be largely attributed to the effects of formic acid rather than ammonia.

Yeasts have been found to be particularly tolerant of formic acid (Henderson et al., 1972). Thus, formic acid has been found effective at prolonging aerobic stability if bacteria, but not yeasts, were the primary cause of the aerobic deterioration (Crawshaw et al., 1980). High concentrations of ethanol are usually associated with large numbers of yeasts (McDonald et al., 1991). The positive effects of AT-hi on aerobic stability and the generally low concentrations of ethanol (approximately $15 \mathrm{~g} / \mathrm{kg}$ of DM or lower) in the untreated and AT-hi silages suggests that yeasts may not have been the primary initiators of aerobic deterioration in our study.

The modest effects of ${ }^{\text {ho }} \mathrm{LAB}$ on the silage fermentation agree with previous findings (Muck and Bolsen, 1991; Kung et al., 2003). The small effects of ho LAB on harvests 1 and 3 may be attributed to high numbers of epiphytic LAB on the herbage at ensiling, as shown previously under similar conditions (Moran et al., 1991). In contrast, the small effects of ${ }^{\text {ho }} \mathrm{LAB}$ on harvest 2 were most likely caused by insufficient fermentable substrate for the added LAB together with overwhelming competition from undesirable bacteria such as clostridia and enterobacteria (Muck and Bolsen, 1991). However, the greatest weakness of ho ${ }^{\mathrm{L}} \mathrm{AB}$ in comparison with the untreated, AT-lo, and AT-hi silages was its typically shorter duration of aerobic stability despite having only a modest effect on the fermentation profile and concentration of residual WSC. The mechanism of aerobic deterioration of silage is complex and need not be closely related to silage chemical composition characteristics (O'Kiely, 1989). Notwithstanding, as the current study and others (Kung et al., 2003) demonstrate, there is a tendency for inoculation with homofermentative LAB to shorten aerobic stability in silages.

\section{Lactobacillus buchneri plus Homofermentative LAB}

Homofermentative LAB are added to silage to stimulate lactic acid fermentation, accelerating the decrease in $\mathrm{pH}$ and thus improving silage fermentation. Unfortunately, as this study and others (Woolford, 1984; McDonald et al., 1991; Kung et al., 2003) demonstrate, homofermentative LAB can shorten the aerobic stability of silage. Lactobacillus buchneri is a biological alternative that has been shown to improve aerobic stability in a variety of crops (Kung et al., 2003). Its effectiveness has been primarily attributed to a reduction in the proliferation of yeasts via the production of acetic acid, which is highly antimycotic (Kleinschmit and Kung, 2006). Yeasts are the most common cause of aerobic deterioration in silage, although bacteria can sometimes be important (McDonald et al., 1991). Driehuis et al. (2001) found that inoculating with a mixture of L. buchneri plus homofermentative LAB combined the positive effects of both types of LAB on silage aerobic stability and fermentation.

In contrast to Driehuis et al. (2001), our study found that ${ }^{\text {he+ho }} \mathrm{LAB}$ was not effective in improving the silage fermentation relative to the untreated control. There are 2 possible explanations for our finding. One possibility is that the added homofermentative LAB in the he+ho LAB inoculant did not dominate the fermentation. The number of homofermentative LAB supplied in the ${ }^{\text {he+ho }} \mathrm{LAB}$ inoculant was calculated to be 10 -fold lower than the minimum recommended application rate of $10^{5} \mathrm{cfu} / \mathrm{g}$ of fresh herbage (Kung et al., 2003). The ${ }^{\text {ho }} \mathrm{LAB}$ treatment supplied $1.8 \times 10^{6} \mathrm{cfu}$ of homofermentative LAB per gram of fresh herbage and had a positive effect on the lactic acid fermentation of silages made from harvest 1, but was ineffective in improving the fermentation of silages made from harvests 2 and 3 . This suggests that the low number of homofermentative LAB supplied in the ${ }^{\text {he+ho }} \mathrm{LAB}$ inoculant may have 
been a contributing factor to the failure of he+ho $\mathrm{LAB}$ to improve the fermentation of silages made from harvest 1. However, factors in addition to the low number of added homofermentative LAB were primarily responsible for the failure of the added homofermentative LAB in ${ }^{\text {he+ho }} \mathrm{LAB}$ to dominate and improve the fermentation of silages made from harvests 2 and 3. Muck and Bolsen (1991) and Kung et al. (2003) outline several reasons why inoculant bacteria do not always dominate the fermentation.

A second possibility why he+ho LAB failed to improve the overall fermentation may be because of the fermentation pathway and characteristics of L. buchneri. It is feasible that in an inoculant containing a mixture of $L$. buchneri plus homofermentative $\mathrm{LAB}$, the positive effects of the added homofermentative LAB during the fermentation phase may be diminished or counteracted by the activity of L. buchneri during the stable phase. Lactobacillus buchneri is understood to have only a minor role during the primary fermentation phase (Driehuis et al., 2001); however, during the stable phase it degrades lactic acid to equimolar amounts of acetic acid and 1,2 propanediol and trace amounts of ethanol (Oude Elferink et al., 2001), leading to an increase in pH and ammonia-N (Driehuis et al., 2001; Kleinschmit and Kung, 2006). It is likely that the activity of $L$. buchneri in he+ho LAB was responsible for worsening the fermentation of silages made from harvest 1 compared with the untreated and ho $\mathrm{LAB}$ silages by reducing lactic acid and increasing acetic acid concentrations, thereby making conditions less inhibitory to clostridia resulting in the production of butyric acid. The negative effects of $L$. buchneri on the fermentation may have been worse with a prolonged storage time, which would have facilitated greater clostridial activity. However, the negative effects of $L$. buchneri on the silage fermentation at harvest 1 were not repeated at harvests 2 and 3 . From harvest 2 , there were no differences among the ho ${ }^{\circ} \mathrm{AB}$, ${ }^{\text {he }+ \text { ho }} \mathrm{LAB}$, and untreated silages in their concentrations of fermentation products, suggesting L. buchneri could not compete with the overwhelming competition from the epiphytic populations of bacteria such as the enterobacteria and clostridia, especially given the high $\mathrm{pH}$ and the lack of fermentable substrate. Oude Elferink et al. (2001) found that the activity of L. buchneri decreased with increasing $\mathrm{pH}$ and that at a $\mathrm{pH}$ above 5.8 hardly any lactic acid degradation by L. buchneri was observed. It was surprising that the differences in lactic and acetic acid concentrations between the ${ }^{\text {he+ho }} \mathrm{LAB}$ and untreated silages made from harvest 3 were either very small or absent depending on cultivar. Driehuis et al. (2001) found that the effects of L. buchneri on fermentation products increased with decreasing DM concentration. However, given the comparative effects of he+ho $\mathrm{LAB},{ }^{\text {ho }} \mathrm{LAB}$, and the untreated control on the lactic and acetic acid concentrations of silages made from harvest 1 (high-DM silage) and harvest 3 (medium-DM silage), the effective activity of L. buchneri in our study appeared to decrease with decreasing DM concentration.

Generally, inoculating silages with L. buchneri alone or in combination with homofermentative LAB has resulted in lower or similar concentrations of WSC in silages (Driehuis et al., 2001; Kleinschmit and Kung, 2006) because, in addition to lactic acid, L. buchneri can use glucose as a substrate when it is available (Oude Elferink et al., 2001). The results of our study agree with these previous findings. If residual WSC concentration is to be consistently increased in silages treated with $L$. buchneri, it appears necessary that L. buchneri is applied in combination with another ingredient that reliably conserves or supplies more WSC during the primary fermentation than is fermented by L. buchneri during the stable phase. The results of our study and Driehuis et al. (2001) confirm that homofermentative $\mathrm{LAB}$ are not ideal to that end.

Compared with ${ }^{\text {ho }} \mathrm{LAB}$, treatment with ${ }^{\text {he }+ \text { ho }} \mathrm{LAB}$ increased the duration of aerobic stability in one-third of the silages, which may be caused at least in part by an increase in acetic and butyric acid concentrations. In general, the higher the level of fermentation acids, and in particular acetic and butyric acids, the more aerobically stable the silage will likely be (Muck and Bolsen, 1991). However, Muck (2004) found L. buchneri improved aerobic stability in the absence of significant shifts in fermentation products, suggesting that other mechanisms may also be involved. In comparison with the untreated, AT-lo, and AT-hi silages, treatment with he+ho LAB was less successful and improved aerobic stability in only one-sixth of the silages. However, the improvements were a consequence of worsening the standard of fermentation, as indicated by an increase in the concentrations of butyric acid or ammonia- $\mathrm{N}$ (corrected). Overall, the failure of he+ho LAB to reliably improve aerobic stability in comparison with the untreated, AT-lo, AT-hi, and ${ }^{\text {ho }} \mathrm{LAB}$ silages is indicative of the relatively minor recorded effects of he+ho $\mathrm{LAB}$ on the fermentation profile and, in the case of AT-lo and AThi, the strong antibacterial properties of formic acid.

\section{Mixture of $\mathrm{NaB}, \mathrm{NaP}, \mathrm{NaN}$, and Hexamine}

Mixtures of $\mathrm{NaB}, \mathrm{NaP}, \mathrm{NaN}$, and hexamine have been found to restrict the activity of LAB, clostridia, and fungi in silages (Lingvall and Lättemäe, 1999; Knický and Lingvall, 2004; Müller, 2005). The action is primarily antimicrobial rather than acidifying. However, as the current and above studies demonstrate, the effects 
have been found to vary depending primarily on the challenge provided by the chemical composition and epiphytic microbial population of the herbage ensiled, as indicated by the fermentation profile of the untreated control silages.

In agreement with the findings of Müller (2005), AMlo and AM-hi had a relatively modest effect on the fermentation profile of the high-DM herbages (harvest 1; approximately $365 \mathrm{~g}$ of $\mathrm{DM} / \mathrm{kg}$ ) that, when ensiled with no additive, produced a dominant lactic acid fermentation with low concentrations of volatile fatty acids and ethanol. Bacterial activity is naturally restricted at higher DM concentrations (McDonald et al., 1991) and, thus, the potential influence of AM-lo and AM-hi on bacterial fermentation was limited. Yeasts are relatively moisture tolerant (McDonald et al., 1991) but, as indicated by the ethanol concentrations of the untreated silages, yeast activity did not appear to be high in our study. If yeast activity is naturally low, the potential antimycotic effects of AM-lo and AM-hi must also be limited.

From harvest 3, the AM-lo and AM-hi additives were tested on herbages of moderate DM concentration (approximately $250 \mathrm{~g}$ of $\mathrm{DM} / \mathrm{kg}$ ) and, under the conditions of our study, consistently reduced lactic acid and increased acetic acid concentrations, in agreement with McEniry et al. (2007). The restriction in the lactic acid fermentation may be attributed primarily to the antimicrobial activity of hexamine, but also in part to the inhibitory effects of $\mathrm{NaB}, \mathrm{NaP}$, and $\mathrm{NaN}$ (Woolford, 1984). Acetic acid in silage is mainly an end product of fermentation by the enterobacteria or LAB (McDonald et al., 1991). In the mixed-acid fermentation by enterobacteria, equimolar amounts of acetic acid and ethanol are produced. The lack of increase in ethanol concentration suggests that the enterobacteria were not responsible for the increase in acetic acid production in the AM-lo and AM-hi silages. Therefore, the increase in acetic acid production is most likely a result of the LAB. One possibility is an increase in the fermentation of hexoses by the heterofermentative LAB, perhaps because the AM-lo and AM-hi additives inhibited the homofermentative LAB more than the heterofermentative LAB. However, this contradicts the findings of Woolford (1975a,b), who found that $\mathrm{NaB}, \mathrm{NaN}$, propionic acid, and hexamine each tended to inhibit heterofermentative LAB to a greater extent than homofermentative LAB. The second possibility is that the addition of AM-lo and AM-hi encouraged an increase in the fermentation of herbage organic acids by LAB. The effects of AM-lo and AM-hi on the fermentation profile were rate-dependent. Treatment with AM-hi had a much greater effect than AM-lo on modifying lactic and acetic acid concentrations and as a result AM-hi also underwent a secondary fermentation, as indicated by an increase in butyric acid concentrations. Acetic acid is a much weaker acid than lactic acid. An increase in acetic acid production at the expense of lactic acid slows the rate of $\mathrm{pH}$ decline and increases the final $\mathrm{pH}$, thereby encouraging clostridial growth (Muck and Bolsen, 1991).

The low-DM herbages (harvest 2; approximately 145 $\mathrm{g}$ of $\mathrm{DM} / \mathrm{kg}$ ) offered a much sterner challenge to the additives from clostridia, as indicated by the high concentrations of butyric acid in the untreated silages. Our results indicated that AM-lo and AM-hi could not reliably produce satisfactorily fermented silages (medium to high standard of fermentation classification) from herbages that naturally underwent such a clostridial dominant fermentation. The effects depended on the extent of the clostridial activity. Similar to previous findings (Lättemäe and Lingvall, 1996; Lingvall and Lättemäe, 1999), our study demonstrated that AM-lo and AM-hi could not produce silages of satisfactory standard of fermentation under conditions where high levels of formic acid or formic acid-based additives (i.e., AT-hi) also produced badly fermented clostridial silages. Thus, the effects of AM-lo and AM-hi on the standard of fermentation of the herbages that were difficult to ensile were comparable to AT-lo and AT-hi, respectively.

Overall, AM-lo and AM-hi did not reliably improve the standard of fermentation of silages over the untreated, AT-lo, or AT-hi additives, producing on average more silages with a lower standard of fermentation classification. The effects varied only slightly with application rate. Overall, increasing the application rate of the antimicrobial mixture from AM-lo to AM-hi had a negligible effect on the standard of fermentation.

The effects of AM-lo and AM-hi on residual WSC were inconsistent and suggested AM-lo and AM-hi offered a relatively modest option to enhance residual WSC. In one-third of comparisons, the AM-lo or AM-hi silages had higher concentrations of residual WSC than the untreated controls. However, the AM-lo and AM-hi silages never had higher residual WSC than AT-lo or AT-hi but often had lower concentrations. In summary of previous studies (Lättemäe and Lingvall, 1996; Lingvall and Lättemäe, 1999; Knický and Lingvall, 2004; Müller, 2005; McEniry et al., 2007), silages treated with a mixture of $\mathrm{NaB}, \mathrm{NaP}, \mathrm{NaN}$, and hexamine had higher $(P<0.05)$ concentrations of residual WSC than the untreated controls in $55 \%$ of comparisons and than the formic acid-treated silages in $20 \%$ of comparisons. The effects of AM-lo and AM-hi on residual WSC may have been greater had yeasts played a more influential role. Yeasts are not significantly inhibited by the $\mathrm{pH}$ levels normally reached during ensiling and, under anaerobic 
conditions, actively ferment sugars (McDonald et al., 1991). Treatment with AM-lo or AM-hi could have potentially inhibited yeast growth during the stable phase, thereby conserving extra WSC and increasing residual WSC at silo opening.

One of the main objectives in applying the antimicrobial mixture to herbage at ensiling was to improve the aerobic stability of silages. However, we found AM-lo and AM-hi to be only moderately successful in achieving this goal. Examination of the aerobic stability results in isolation masks the fact that the improvement in aerobic stability over the untreated silages was sometimes caused by a lower standard of fermentation rather than the specific antimicrobial effects of AM-lo or AM-hi per se. Poorly fermented silages are often more aerobically stable than well-fermented silages because of a greater concentration of volatile fatty acids and the antimicrobial properties of these fatty acids (McDonald et al., 1991). An increase in aerobic stability is not a substitute for an unsatisfactory standard of fermentation. Previous studies have found mixtures of $\mathrm{NaB}, \mathrm{NaP}, \mathrm{NaN}$, and hexamine to improve aerobic stability and attributed the effects to a reduction in yeast activity (Knický and Lingvall, 2004; Müller, 2005; McEniry et al., 2007). Our study indicated that AM-lo and AM-hi may not be successful in improving aerobic stability under all conditions, particularly where yeasts may not have been the major initiators of aerobic deterioration.

\section{Cultivar}

The WSC advantage of AberDart over Fennema at ensiling was consistent with previous findings (Conaghan et al., 2008), with AberDart producing herbage with on average $12 \%$ higher concentrations of WSC expressed on a DM basis. Differences between cultivars in their silage characteristics when ensiled without additive application confirmed that the cultivars offered a unique test for the additives. Untreated AberDart silages generally had a shorter duration of aerobic stability than corresponding Fennema silages. The effect of cultivar on residual WSC concentration was inconsistent across harvests. However, AberDart demonstrated its potential to produce silages with higher concentrations of residual WSC given a restricted, lactic acid-dominant fermentation, producing untreated silages from harvest 1 with more than 2-fold higher residual WSC than corresponding Fennema silages. These results confirm that testing the additives across AberDart and Fennema offered a more complete and stringent test of the additives' ability to enhance residual WSC concentration and protect aerobic stability.

\section{CONCLUSIONS}

The ${ }^{\text {he+ho }}{ }^{\mathrm{LAB}}$ inoculant had no beneficial effect on silage fermentation compared with the untreated control and AT-lo, AT-hi, and ${ }^{\text {ho }} \mathrm{LAB}$ additives, producing silages of similar or slightly lower standard of fermentation. The antimicrobial treatments AM-lo and AM-hi occasionally improved the standard of fermentation depending on the treatment of comparison but, on average, produced more silages of lower standard of fermentation than the untreated control and AT-lo, AT-hi, and ho LAB additives. The ${ }^{\text {he+ho }}$ LAB inoculant was not effective in increasing residual WSC concentration, producing silages with similar or lower concentrations than the other additive treatments. The antimicrobial treatments offered a relatively modest option to increase residual WSC concentration, producing silage with occasionally higher concentrations than the untreated control and ${ }^{\text {ho }} \mathrm{LAB}$ additive but similar or lower concentrations than AT-lo and AT-hi. The ${ }^{\text {ho }} \mathrm{LAB}$ silages were generally the least aerobically stable. The he+ho LAB and AM-lo could not consistently protect aerobic stability and secure an intermediate to long duration of aerobic stability across all herbages. The AM-hi additive consistently produced silages with an intermediate to long duration of aerobic stability, but the effects were sometimes confounded with the effects of a poorer standard of fermentation. Ammonium tetraformate at $6 \mathrm{~L} / \mathrm{t}$ (AT-hi) was the most effective additive evaluated in this study, producing more silages of higher standard of fermentation and residual WSC concentration than any other additive treatment, combined with an intermediate to long duration of aerobic stability.

\section{ACKNOWLEDGMENTS}

The authors thank Per Lingvall (Swedish University of Agricultural Sciences, Uppsala, Sweden), Roger Merry (Institute of Grassland and Environmental Research, Aberystwyth, UK), and Güenter Pahlow (Federal Agricultural Research Centre, Braunschweig, Germany) for provision of additives; Jim Hamill and John Marron of Teagasc, Grange Beef Research Centre (Dunsany, Ireland) for technical support; the Grange Beef Research Centre farm staff (and in particular Jack Lynch) for plot management and assistance with making silage; and the Grange Beef Research Centre laboratory staff for chemical analyses. A Teagasc Walsh Fellowship awarded to Patrick Conaghan and funding from the European Commission under the Fifth Framework Programme (QLK5-CT-2001-0498) supported this research. 


\section{REFERENCES}

AOAC. 1990. Protein (crude) in animal feed, combustion method, 990.03. Pages 18-19 in Official Methods of Analysis of the Association of Official Analytical Chemists. 15th ed. AOAC, Arlington, VA.

Conaghan, P., P. O'Kiely, H. Howard, F. P. O'Mara, and M. A. Halling. 2008. Evaluation of Lolium perenne L. cv. AberDart and AberDove for silage production. Ir. J. Agric. Food Res. 47:119-134.

Crawshaw, R., D. M. Thorne, and R. H. Llewelyn. 1980. The effects of formic and propionic acids on the aerobic deterioration of grass silage in laboratory units. J. Sci. Food Agric. 31:685-694.

Driehuis, F., S. J. W. H. Oude Elferink, and P. G. Van Wikselaar. 2001. Fermentation characteristics and aerobic stability of grass silage inoculated with Lactobacillus buchneri, with or without homofermentative lactic acid bacteria. Grass Forage Sci. 56:330343.

Givens, D. I., and H. Rulquin. 2004. Utilisation by ruminants of nitrogen compounds in silage-based diets. Anim. Feed Sci. Technol. 114:1-18.

Henderson, A. R., P. McDonald, and M. K. Woolford. 1972. Chemical changes and losses during the ensilage of wilted grass treated with formic acid. J. Sci. Food Agric. 23:1079-1083.

Jarvis, S. C., R. J. Wilkins, and B. F. Pain. 1996. Opportunities for reducing the environmental impact of dairy farming managements: A systems approach. Grass Forage Sci. 51:21-31.

Kleinschmit, D. H., and L. Kung Jr.. 2006. A meta-analysis of the effects of Lactobacillus buchneri on the fermentation and aerobic stability of corn and grass and small-grain silages. J. Dairy Sci. 89:4005-4013.

Knický, M., and P. Lingvall. 2004. Ensiling of high wilted grass-clover mixture by use of different additives to improve quality. Acta Agric. Scand. Sect. A Anim. Sci. 54:197-205.

Kung, L., Jr., M. R. Stokes, and C. J. Lin. 2003. Silage additives. Pages 305-360 in Silage Science and Technology. D. R. Buxton, R. E. Muck, and J. H. Harrison, ed. Am. Soc. Agron., Crop Sci. Soc. Am., and Soil Sci. Soc. Am., Madison, WI.

Lättemäe, P., and P. Lingvall. 1996. Effect of hexamine and sodium nitrite in combination with sodium benzoate and sodium propionate on fermentation and storage stability of wilted and long cut grass silage. Swed. J. Agric. Res. 26:135-146.

Lingvall, P., and P. Lättemäe. 1999. Influence of hexamine and sodium nitrite in combination with sodium benzoate and sodium propionate on fermentation and hygienic quality of wilted and long cut grass silage. J. Sci. Food Agric. 79:257-264.

Lister, S. J., and M. S. Dhanoa. 1998. Comparison of calibration models for the prediction of forage quality traits using near infrared spectroscopy. J. Agric. Sci. 131:237-243.

McDonald, P., A. R. Henderson, and S. J. E. Heron. 1991. The Biochemistry of Silage. 2nd ed. Chalcombe Publ., Marlow, UK.

McEniry, J., P. O'Kiely, N. J. W. Clipson, P. D. Forristal, and E. M. Doyle. 2007. Manipulating the ensilage of wilted, unchopped grass through the use of additive treatments. Ir. J. Agric. Food Res. 46:77-91.

Merry, R. J., M. R. F. Lee, D. R. Davies, R. J. Dewhurst, J. M. Moorby, N. D. Scollan, and M. K. Theodorou. 2006. Effects of high-sugar ryegrass silage and mixtures with red clover silage on ruminant digestion. 1 . In vitro and in vivo studies of nitrogen utilization. J. Anim. Sci. 84:3049-3060.
Moorby, J. 2001. Grass sugars make milk production sweeter. IGER Innovations 5:35-39.

Moran, J. P., P. O'Kiely, R. K. Wilson, and M. B. Crombie-Quilty. 1991. Lactic acid bacteria levels on grass grown for silage in Ireland. Landbauforschung Volkenrode 123:283-286.

Muck, R. E. 2004. Effects of corn silage inoculants on aerobic stability. Trans. ASAE 47:1011-1016.

Muck, R. E., and K. K. Bolsen. 1991. Silage preservation and silage additive products. Pages 105-126 in Field Guide for Hay and Silage Management in North America. K. K. Bolsen, J. E. Baylor, and M. E. McCullough, ed. Natl. Feed Ingred. Assoc., West Des Moines, IA.

Müller, C. E. 2005. Fermentation patterns of small-bale silage and haylage produced as a feed for horses. Grass Forage Sci. 60:109 118.

O'Keeffe, M., and J. Sherrington. 1983. Comparison of three methods for determination of urea in compound feed and silage. Analyst (Lond.) 108:1374-1379

O'Kiely, P. 1989. Aerobic stability of farm silages. Pages 4-5 in Proc. 15th Ann. Res. Mtg. of the Irish Grassland and Animal Production Assoc.. University College Dublin, Ireland.

O'Kiely, P., and R. K. Wilson. 1991. Comparison of three silo types used to study in-silo processes. Ir. J. Agric. Res. 30:53-60.

Oude Elferink, S. J. W. H., J. Krooneman, J. C. Gottschal, S. F. Spoelstra, F. Faber, and F. Driehuis. 2001. Anaerobic conversion of lactic acid to acetic acid and 1,2-propanediol by Lactobacillus buchneri. Appl. Environ. Microbiol. 67:125-132.

Playne, M. J., and P. McDonald. 1966. The buffering constituents of herbage and of silage. J. Sci. Food Agric. 17:264-268.

Porter, M. G., and R. S. Murray. 2001. The volatility of components of grass silage on oven drying and the inter-relationship between drymatter content estimated by different analytical methods. Grass Forage Sci. 56:405-411.

Ranfft, K. 1973. Determination by gas chromatography of short-chain acids in ruminal fluids. Arch. Tierernahr. 23:343-352.

Rotz, C. A., and R. E. Muck. 1994. Changes in forage quality during harvest and storage. Pages 828-868 in Forage Quality, Evaluation and Utilization. G. C. Fahey Jr., ed. Am. Soc. Agron., Crop Sci. Soc. Am., and Soil Sci. Soc. Am., Madison, WI.

Shingfield, K. J., S. Jaakkola, and P. Huhtanen. 2001. Effects of level of nitrogen fertilizer application and various nitrogenous supplements on milk production and nitrogen utilization of dairy cows given grass silage-based diets. Anim. Sci. 73:541-554.

Tilley, J. M. A., and R. A. Terry. 1963. A two-stage technique for the in vitro digestion of forage crops. J. Br. Grassl. Soc. 18:104-111.

Van Soest, P. J. 1967. Development of a comprehensive system of feed analyses and its application to forages. J. Anim. Sci. 26:119128

Wilson, R. K. 1978. Estimation of water soluble and individual carbohydrates in grass samples. Page 46 in Proc. Euro-analysis, Dublin. Applied Science Publishers Ltd., London, UK.

Woolford, M. K. 1975a. Microbiological screening of the straight chain fatty acids $\left(\mathrm{C}_{1}-\mathrm{C}_{12}\right)$ as potential silage additives. J. Sci. Food Agric. 26:219-228.

Woolford, M. K. 1975b. Microbiological screening of food preservatives, cold sterilants and specific antimicrobial agents as potential silage additives. J. Sci. Food Agric. 26:229-235.

Woolford, M. K. 1984. The Silage Fermentation. Marcel Dekker, New York, NY. 